\title{
10. DIAGENESIS IN EOCENE CLAYSTONES, ODP SITE 647, LABRADOR SEA: FORMATION OF COMPLEX AUTHIGENIC CARBONATES, SMECTITES, AND APATITE ${ }^{1}$
}

\author{
Gerhard Bohrmann² and Jörn Thiede ${ }^{3}$
}

\begin{abstract}
Authigenic carbonates were recovered in lower to middle Eocene claystones at Ocean Drilling Program Site 647 in the Labrador Sea. Detailed chemical, petrographic, and X-ray investigations reveal that these diagenetic carbonates have a complex mineralogical composition. At least five different carbonate phases are identified: calcium-rich rhodochrosite, rhodochrosite, manganosiderite, siderite, and calcite. Manganese carbonates are the dominant carbonate phases formed throughout the section. Textural analyses show two major generations of carbonate formation. Early cementation of micritic carbonate in burrow structures was followed by carbonate cementation forming microsparry to sparry crystals.

At approximately 620 meters below seafloor (mbsf), three concretions of iron carbonates occur, which indicates a special pore-water chemistry. Thin section analyses from this level show (1) several generations of diagenetic carbonates, (2) widespread secondary cavity formation in burrow structures, and (3) various cement precipitations in voids. We suggest that this level represents a hiatus or highly condensed sequence, as indicated by (1) the low carbonate content in host sediments, (2) carbonate dissolution reflected by the high ratio of benthic to planktonic foraminifers, and (3) complex diagenetic alteration in the carbonate concretions.

Iron and manganese enrichments observed in lithologic Unit IV may have been derived from a hydrothermal source at the adjacent, then active, Labrador Sea mid-ocean ridge. Authigenic smectites forming numerous pseudomorphs of siliceous microfossils are precipitated in burrow structures. We propose that diagenetic smectite formation from biogenic opal and iron oxyhydroxide (analogous to smectite formation in surface sediments of the East Pacific area) occurred in the Labrador Sea during the early and middle Eocene.
\end{abstract}

\section{INTRODUCTION}

Seven hundred meters of pelagic and hemipelagic sediments overlying the oceanic basement were recovered at Site 647 in the southern Labrador Sea at $53^{\circ} 19.876^{\prime} \mathrm{N}, 45^{\circ} 15.717^{\prime} \mathrm{W}$ (water depth of $3861.8 \mathrm{~m}$; Figs. 1 and 2). The sediments are divided into four lithologic units (Fig. 2). The upper unit of the Paleogene section, lithologic Unit III, is characterized by a variety of different biogenic lithologies, whereas the lower lithologic Unit IV contains argillaceous sediments, with minor biogenic constituents (Srivastava, Arthur, et al., 1987). This sequence of claystones (lithologic Unit IV) extends from 699 (directly above the seafloor basalt) to 530 mbsf and exhibits numerous diagenetic features, which are discussed here.

Although core recovery from this deepest sediment unit was poor, diagenetic features seem to be more abundant in Cores 105-647A-64R through 105-647A-68R, starting $40 \mathrm{~m}$ above the seafloor basalt, rather than in sediments directly overlying basaltic basement. Increased diagenetic activity probably was influenced by a lower sedimentation rate and/or a hiatus accompanied by hydrothermal activity (Srivastava, Arthur, et al., 1987). The most striking diagenetic characteristics are an alternation of dusky red to pale red and greenish-gray beds (with violet shades at the green/red contacts) and scattered carbonate concretions.

\footnotetext{
${ }^{1}$ Srivastava, S. P., Arthur, M., Clement, B., et al., 1989. Proc. ODP, Sci. Results, 105: College Station, TX (Ocean Drilling Program).

2 Geologisch-Paläontologisches Institut und Museum der Christian Albrechts Universität zu Kiel, Olshausenstraße 40, D-2300 Kiel 1, Federal Republic of Germany. Present address: Alfred-Wegener Institut Polar-und-Meeresforschung, Columbusstraße, 2850 Bremerhaven, Federal Republic of Germany.

3 GEOMAR, Forshungzentrum für Marine Geowissenschaften an der Universität Kiel, Wischhofstraße 1-3, 2300 Kiel 14, Federal Republic of Germany.
}

Authigenic carbonates have been described from many previous Deep Sea Drilling Project (DSDP) sites (Hein et al., 1979a; Okada, 1980; Pisciotto and Mahoney, 1981; Wada et al., 1982; Kelts and McKenzie, 1982; Matsumoto and Matsuhisa, 1983). However, the occurrence of complex authigenic carbonates with extensive cation substitutions has only been described from a few drill sites (Hein et al., 1979a; Okada, 1980; Wada et al., 1981; Matsumoto and Matsuhisa, 1983; von Rad and Botz, 1987; Henrich, in press). Tassé and Hesse (1984) believed that the abundance of complex authigenic carbonates may have been underestimated by past investigations. Diagenetic carbonates occurring in lithologic Unit IV at Site 647 in the Labrador Sea appear to indicate a complex diagenetic history.

Sedimentological, chemical, and petrological characteristics of the carbonate concretions and related mineralogical constituents were investigated to reconstruct the sedimentary and diagenetic environment.

\section{METHODS}

Twenty-four specimens (13 carbonate concretions and 11 claystone samples) from lithologic Unit IV from Site 647 were studied by X-ray diffraction (XRD), light microscopy, scanning electron microscopy (SEM), and chemical analyses.

Texture and component compositions of the sediment samples were analyzed in thin sections and under the SEM of the Geological Institute, Kiel (S150 Cambridge), at $10 \mathrm{kV}$ connected to an energy-dispersive Xray spectrographic analyzer. The mineralogy of numerous subsamples was identified by X-ray diffraction (Philips diffractometer PW 1050/ $\mathrm{CoK} \alpha$ radiation). Clay minerals were determined following the method of Lange (1982). Carbonate samples were mixed with approximately $10 \%$ ground quartz grains before preparation for XRD. We measured the $\mathrm{d}(104)$ reflections that could be seen well in the $30-38^{\circ} 2 \theta$ interval using a cobalt target (scanning rate of $0.03^{\circ} 2 \theta / \mathrm{s}$ ). The peak positions of the $d(104)$ carbonate reflections were identified using the $d(101)$ quartz peak at $3.343 \AA$ as a standard. The relative amounts of carbonate phases were estimated using peak-intensity ratios, which were defined by their $\mathrm{d}(104)$ peak heights above the background. 


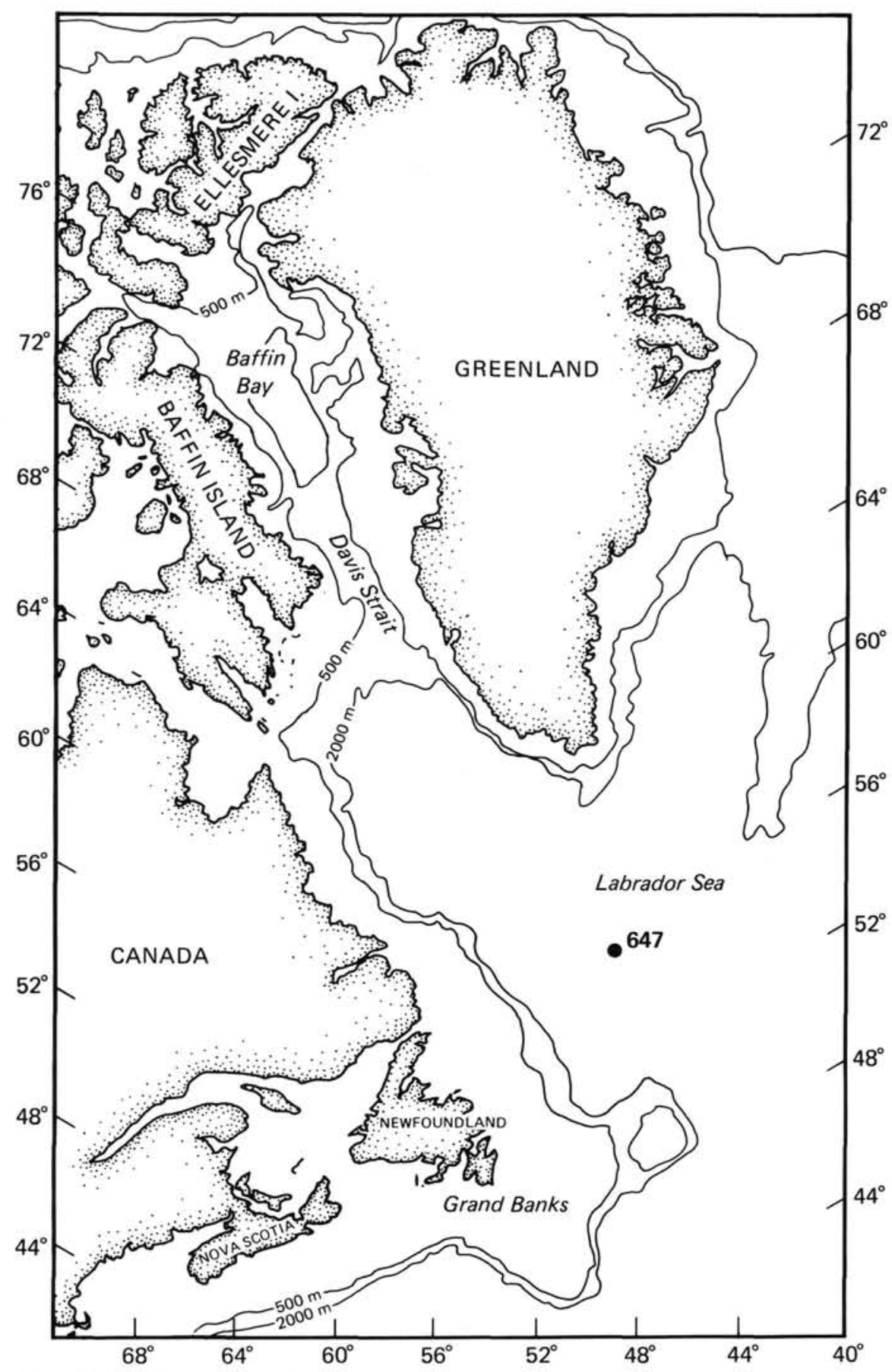

Figure 1. Location of Site 647.

The composition of selected carbonate minerals was determined with a CAMECA microprobe of the Mineralogical Institute, Kiel, equipped with four spectrometers. Calcium, iron, manganese, and magnesium were analyzed at $15 \mathrm{kV}, 15 \mathrm{nA}$ with respect to standards. All analyses having total weight percent ranging from $95 \%-105 \%$ were used and transformed into molar percentages after recalculation to $100 \%$. Carbonate contents were determined by infrared absorption of $\mathrm{CO}_{2}$ that was released by phosphoric acid treatment. Shipboard carbonate data also were used.

Phosphorus content was measured spectrophotometrically as the phosphormolybdate complex (Strickland and Parsons, 1968) after digestion of the sediment by hydrofluoric/hydrochloric/nitric acids. Iron, manganese, calcium, and magnesium of the bulk samples were measured by atomic absorption spectroscopy against standard solutions of metals after sediment samples had been digested in hydrofluoric and perchloric acids.

Several sediment samples were wet-sieved at $63 \mu \mathrm{m}$. The coarse fraction was then dry sieved into several subfractions. About 600 grains from each $125-500 \mu \mathrm{m}$ subsample were counted to determine the ratio of benthic to planktonic foraminifers.

\section{RESULTS}

\section{General Characteristics}

The sediments of lithologic Unit IV are composed of greenish-gray, pale red to dusky red claystones and some lighter foraminifer- and nannofossil-bearing claystones (Srivastava, Arthur, 


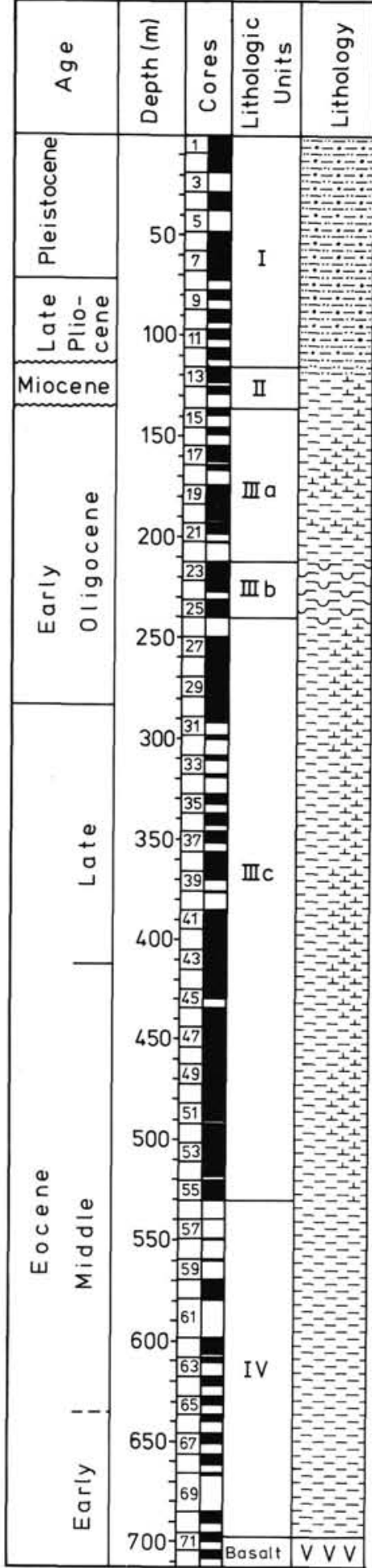

Figure 2. Stratigraphy, lithologies, and lithologic units of Site 647.

et al., 1987). Bioturbation, which indicates an oxygenated depositional environment, occurred throughout. Authigenic carbonates are concentrated in the interval between $617.5-665.9 \mathrm{mbsf}$ (Cores 105-647A-64R through 105-647A-68R). They occur as pale yellowish concretions ranging from small millimeter-sized specks up to $8 \mathrm{~cm}$ (Figs. 3 and 4). Concretionary zones are primarily developed as well-defined nodules, micronodules, lenses, and burrow fills (Fig. 5). However, numerous specks having

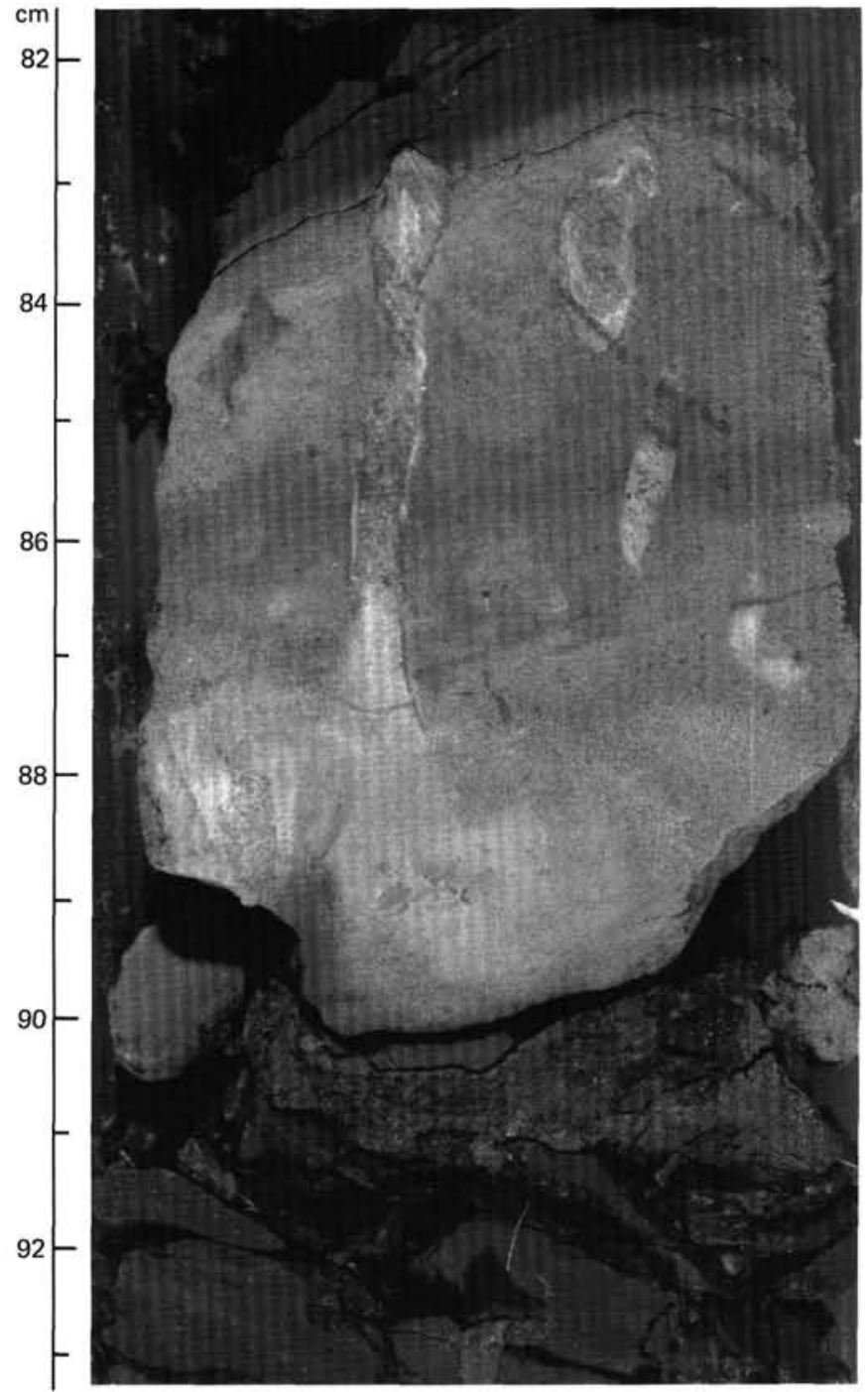

Figure 3. Thick concretionary layer (Sample 105-647A-64R-1, 84-91 cm) of calcium-rich rhodochrosite with burrow-fillings of manganosiderite. Burrow fillings project into the overlying sediment, indicating cementation of the burrow before the main compaction of the sediment.

broad, continuous transition zones into the host sediment and scattered rhombohedral-shaped carbonate crystals also are present. Arthur et al. (this volume) noted and described similar carbonate concretions in the upper part of Unit IV as well.

Macroscopic investigation shows two generations of carbonate precipitation in some large concretions (Figs. 3 and 4). The carbonate concretion layer of Sample 105-647A-64R-1, 84-91 cm (Fig. 3) has remnants of various small and large near-vertical burrows. The burrows are filled by finer-grained, strongly cemented carbonates. The near-vertical burrows project partly into the overlying claystone, indicating that carbonate cementation within the burrows took place earlier than main compaction and lithification of the surrounding sediment. In addition, the concretion of Sample 105-647A-67R-2, 44-46 cm, shows some evidence of deformed stratification (Fig. 4). The deformation structures most probably formed after precipitation of the carbonate nodule was completed but before the consolidation of the host sediment.

\section{Mineralogy and Chemistry of Authigenic Carbonates}

In 14 authigenic carbonate samples studied, the chemistry of carbonate minerals is complex. Substitutions of major cations 

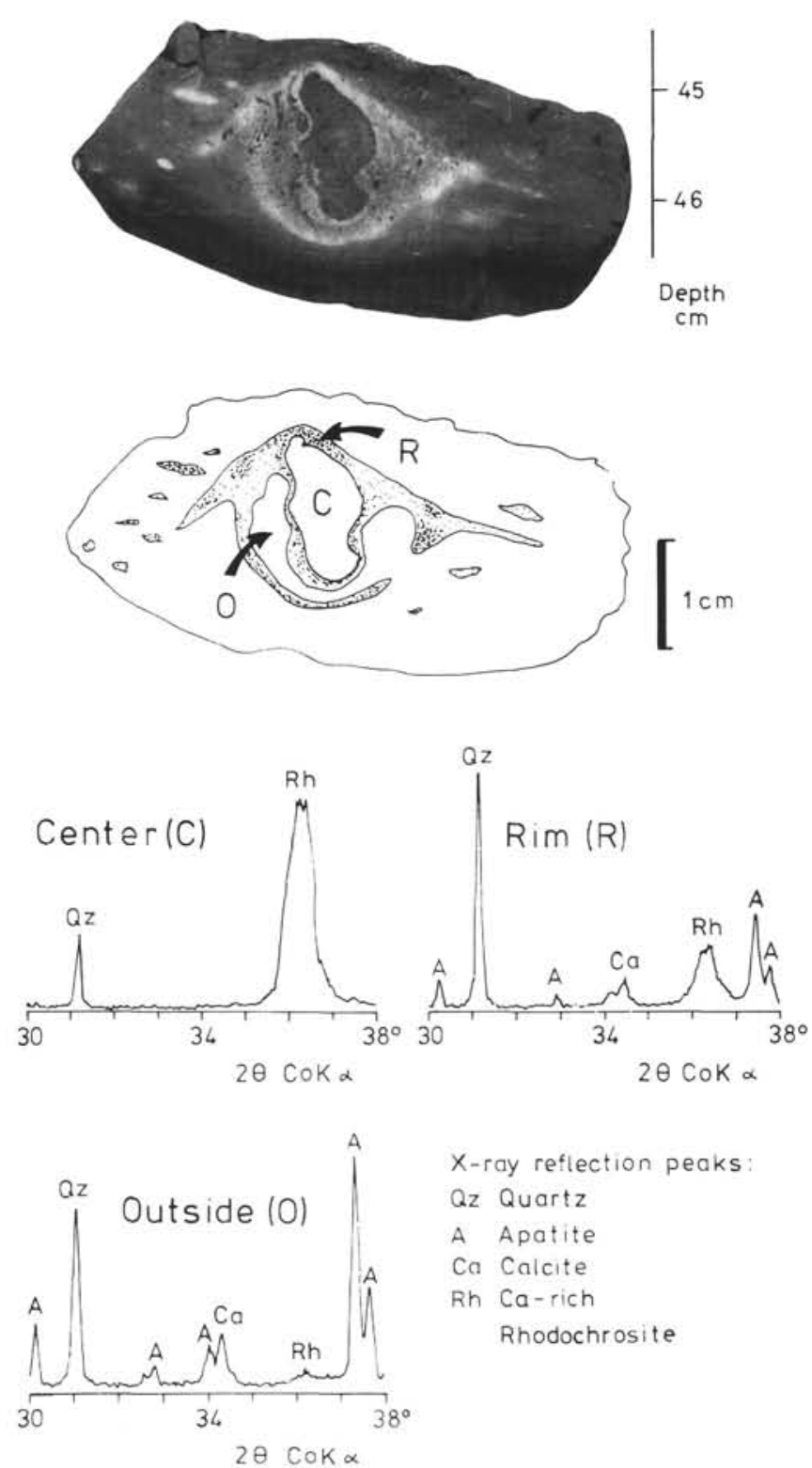

$$
\begin{aligned}
& \text { X-ray reflection peaks: } \\
& \text { Qz Quartz } \\
& \text { A Apatite } \\
& \text { Ca Calcite } \\
& \text { Rh Ca-rich } \\
& \text { Rhodochrosite }
\end{aligned}
$$

$$
2 \theta \operatorname{Cok} \alpha
$$

Figure 4. Closeup photograph and schematic drawing of a complex carbonate concretion (Sample 105-647A-67R-2, 44-46 cm) having a center composed of calcium-rich rhodochrosite (most probably a burrow) and calcite in the rim area and outside. Mineralogy documented in the X-ray reflection records.

(calcium, iron, manganese, magnesium) are extensive. To examine carbonate mineralogy and chemical composition, we have combined X-ray data, analyses of bulk chemical composition, and semiquantitative determinations of major elements by EDAXestimates. In some instances, microprobe chemical data were utilized. Figure 6 displays the amounts of the four major cations from bulk sample measurements. Claystone samples from the host sediments also were analyzed for comparison and are represented in Figure 6 as dots connected by lines. The values determined in concretions are circled and connected to the base curve by horizontal lines. By this way of graphical presentation, enrichment or depletion of the four major cations in the various carbonate layers are compared with the background concentration level.

Carbonate concentrations in the concretions range from $30 \%$ $80 \%$ and average $60 \%-70 \%$. In view of these high carbonate contents and the mineralogy of carbonates and associated noncarbonate minerals, the concentrations of the four cations can be closely related to changes in carbonate phases (Table 1).

Manganese is the dominant cation in the carbonates, followed by calcium (Fig. 6; Table 1). Outside of the authigenic carbonate layers, manganese contents are very low, whereas calcium concentrations vary. The base curve of calcium concentration, excluding values from concretions (Fig. 6), represents variable amounts of biogenic calcite outside the concretionary zones.

Iron is only important $(16 \%-17 \% \mathrm{Fe})$ in the samples of Core 105-647A-64R (Fig. 6), where iron dominates carbonate phases that range between $30 \%-40 \% \mathrm{FeCO}_{3}$ (Table 1). Lower in the stratigraphic column, iron is less abundant in the concretions than in the surrounding claystones. In the carbonate layers, magnesium is lower (Fig. 6) than other cations, which indicates that $\mathrm{MgCO}_{3}$ is of minor importance. Only in three samples of Core $105-647 \mathrm{~A}-64 \mathrm{R}$ does the bulk $\mathrm{MgCO}_{3}$ content exceed $2 \%$.

According to their $\mathrm{d}(104)$ reflections, different carbonate mineral phases are present. Pure carbonate phases are rare. The 14 samples primarily show mixtures of carbonate minerals (Table 1) having large amounts of substituted cations. The exact position of the carbonate X-ray reflection is known to be influenced by cation substitution (Tassé and Hesse, 1984). Shifts from the pure end-member position of a carbonate mineral to smaller or higher peak angles are caused by the amount and ionic size of foreign cations (Goldsmith and Graf, 1958). Based on the X-ray records, at least five carbonate minerals can be distinguished: calcium-rich rhodochrosite, rhodochrosite, manganosiderite, siderite, and calcite.

The most common mineral phase is a manganoan carbonate, which was found in nearly all samples and which dominates the bulk carbonate with concentrations between $50 \%$ and $100 \%$ (Fig. 5). The d(104) reflections of this carbonate phase are broad and show multiple peaks, indicating variations in chemical composition. The $d(104)$ values range from 2.884 to $2.860 \AA$, which is slightly smaller than those of typical dolomite $(2.886 \AA)$ and greater than those of pure rhodochrosite $(2.844 \AA)$. Several microprobe analyses from two carbonate concretions show that chemical variations of these minerals are limited in extent, as expressed by the following molar percentages:

$$
\mathrm{Mn}_{0.72-0.78} \mathrm{Ca}_{0.20-0.23} \mathrm{Mg}_{0.03-0.04} \mathrm{CO}_{3} \text {. }
$$

Based on manganese and calcium content, this mineral was identified as a calcium-rich rhodochrosite. In general, iron amounts are less than $1 \mathrm{~mol} \%$. The content of $\mathrm{FeCO}_{3}$ is near $1 \%$ only in Sample 105-647A-64R-1, $88 \mathrm{~cm}$ (Table 2).

The second most important carbonate, observed in 8 of the 14 samples, is characterized by an average d(104) spacing of $2.844 \AA$, typical for pure rhodochrosite. This peak occurs on the high-angle side of the broad, calcium-rich rhodochrosite peak. Although microprobe analysis did not detect a rhodochrosite phase without impurities, ED/.X measurements also show pure manganese carbonates. However, this mineral is present only in minor amounts.

A third carbonate was detected at angles corresponding to a $\mathrm{d}(104)$ spacing of $2.819-2.827 \AA$. These values are intermediate between the d(104) peaks of rhodochrosite (2.844 $\AA$ ) and siderite $(2.7912 \AA)$. Tassé and Hesse (1984) also found a complex carbonate phase in Cretaceous black shales of the western Alps that was characterized by an average d(104) spacing of $2.81 \AA$. Chemical analyses of their samples showed that $\mathrm{FeCO}_{3}$ was generally more abundant than $\mathrm{MgCO}_{3}$ and $\mathrm{MnCO}_{3}$. They were able to identify this mineral phase as a manganese- and magnesium-rich siderite. Similar descriptions were given by von Rad and Botz (1987) to define an isomorphous mixture of 


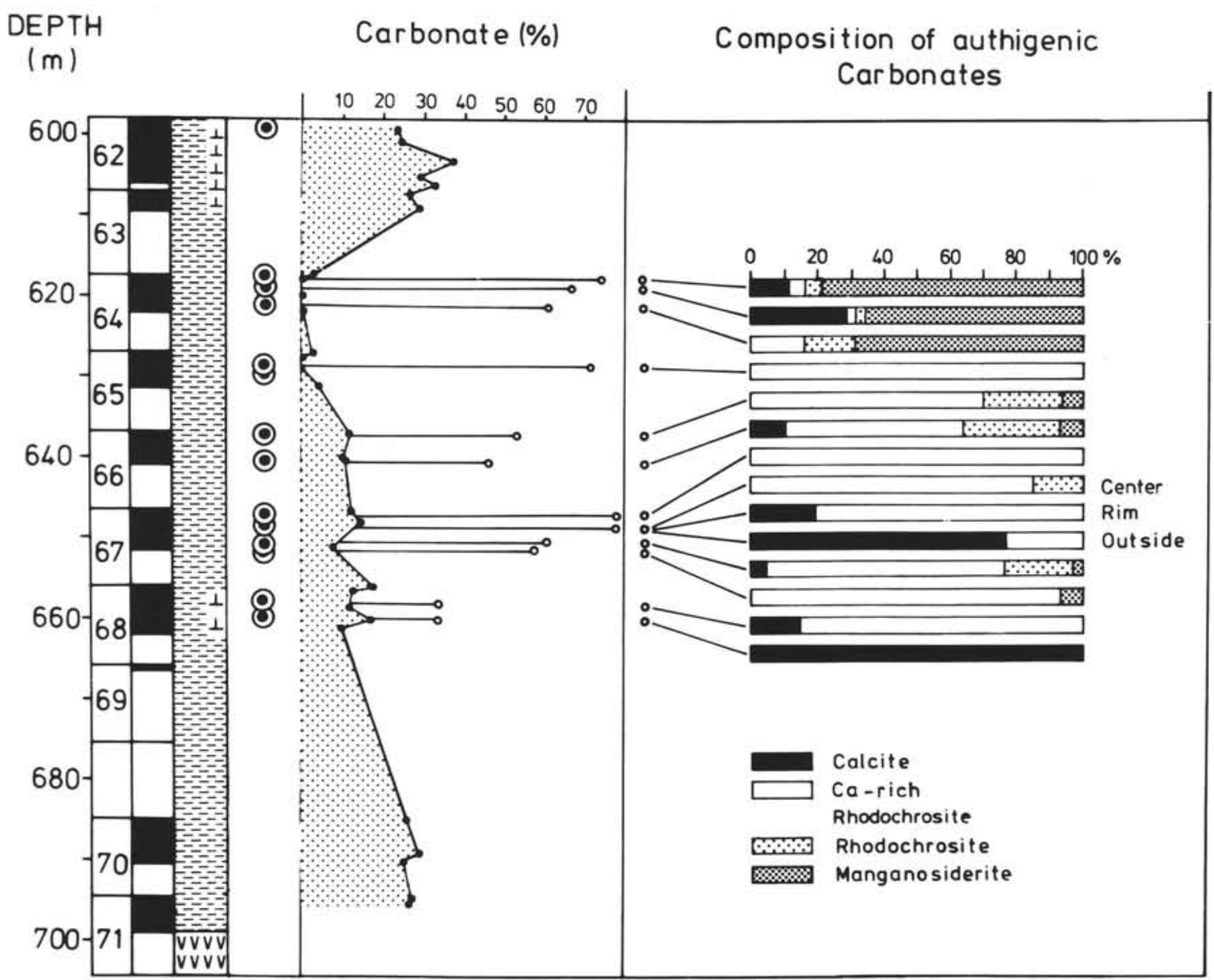

Figure 5. Position and composition of authigenic carbonate concretions greater than $3 \mathrm{~cm}$ in the investigated interval of Site 647. Carbonate values of the concretions are drawn by horizontal lines.

rhodochrosite and siderite with an intermediate d(104) spacing as manganosiderite. Numerous EDAX measurements from our samples showed that iron and manganese are the major cations, with the iron contents slightly exceeding those of manganese. Microprobe analyses (Table 2) from these carbonates indicate an average composition, with only small deviations, of $\mathrm{Mn}_{0.34} \mathrm{Fe}_{0.43} \mathrm{Ca}_{0.12} \mathrm{Mg}_{0.11} \mathrm{CO}_{3}$. According to these measurements, all four cations are present, but manganese and iron dominate (see also Arthur et al., this volume). Because this carbonate phase contains more iron than manganese, the mineral could be described as a manganese-rich siderite or, according to von Rad and Botz (1987), it may be designated manganosiderite. This mineral was the major carbonate phase in all three samples of Core 105-647A-64R (-64R-1, $39 \mathrm{~cm}$; -64R-1, $88 \mathrm{~cm}$; -64R-3, 64 $\mathrm{cm})$. In deeper levels, however, it is present only in small amounts. Occurrence of manganosiderite in the samples of Core 105647A-64R agrees well with the bulk chemical data (Fig. 6) that shows higher amounts of iron than manganese at the same sample levels.

In a few microprobe analyses, a fourth carbonate phase clearly was identified as siderite $\left(\mathrm{Mn}_{0.15} \mathrm{Fe}_{0.55} \mathrm{Ca}_{0.14} \mathrm{Mg}_{0.16} \mathrm{CO}_{3}\right)$ having a lower manganese content than the common manganosiderite phase. Using linear interpolation of the cation molar percentages, calculation of an average d(104) spacing for this mineral gives a value of about $2.82 \AA$ on X-ray diffractograms. This phase cannot be distinguished from the manganosiderite peak. Based on thin section investigations, the amount of the pure siderite phase is subordinate. No major change in the concentration of manganosiderite (Fig. 5) occurs when this siderite mineral is omitted.
The fifth authigenic carbonate mineral detected in the samples is calcite, which has $d(104)$ values ranging from 3.032 to $3.028 \AA$, slightly less than for pure calcite $(3.036 \AA)$. This is a result of minor substitution by noncalcium ions having smaller ionic radii. The lowermost carbonate sample (105-647A-68R-2, $111 \mathrm{~cm}$ ) is composed entirely of calcite. The two uppermost carbonate concretions (105-6476A-4R-1, $39 \mathrm{~cm}$; 105-647A-64R-1, $88 \mathrm{~cm}$ ) show broader and different d(104) calcite reflections ( $3.010 \AA$ and $3.013 \AA$ ), which indicates larger amounts of foreign cations. The elemental composition seen in EDAX-spectra implies that calcium is partially substituted by manganese and iron. This agrees well with microprobe measurements (Table 2) in a blocky cement of Sample 105-647A-64R-1, $88 \mathrm{~cm}$, and indicates an average composition of $\mathrm{Mn}_{0.04} \mathrm{Fe}_{0.05} \mathrm{Ca}_{0.90} \mathrm{Mg}_{0.01} \mathrm{CO}_{3}$. Note that in both samples, where impure calcite is present, manganosiderite is the most common carbonate phase.

\section{Petrographic Description of the Authigenic Carbonates}

The macroscopically observed burrow fills, which were found in approximately one-half of all concretionary zones, also can be recognized by their microtexture. Despite changes in mineralogical composition, all burrows in the concretions contain micritic carbonate and are further characterized by a high degree of induration. The micritic carbonate matrix $(1-4 \mu \mathrm{m})$ is primarily composed of densely packed xenomorphic carbonate crystals (Pl. 1, Figs. 1 and 2). In some parts of the burrow fills, the uniform mosaics of the micritic matrix were changed to microspar by neomorphic processes. These neoformed carbonate crystals, occurring mostly in patches, have grain sizes of 8-15 


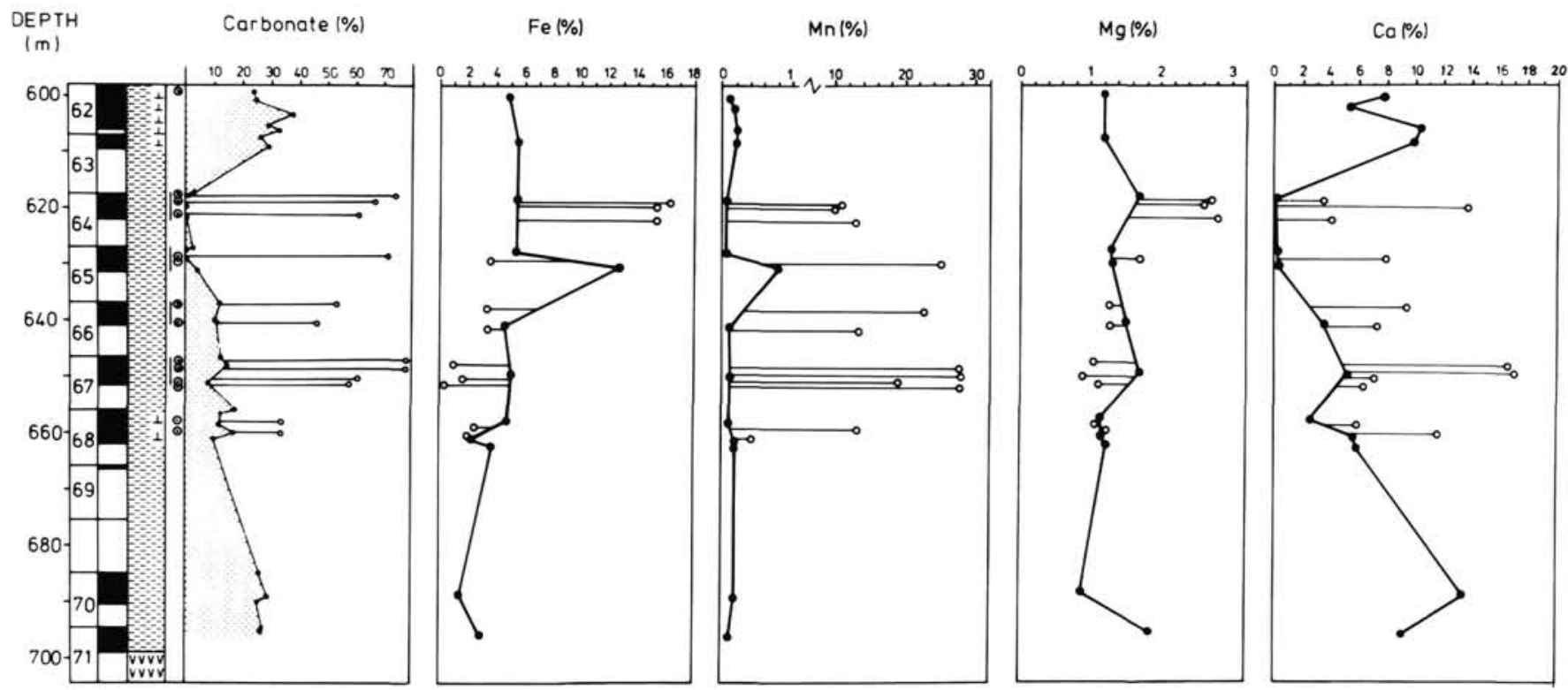

Figure 6. Distribution of major cations from the investigated interval of Site 647. Values for the concretionary zones are connected by horizontal lines with the base curve representing data from the claystone lithologies.

Table 1. Estimated amounts of different carbonate minerals based on $\mathrm{X}$-ray diffraction.

\begin{tabular}{|c|c|c|c|c|c|c|c|c|c|c|}
\hline $\begin{array}{c}\text { Sample } \\
\text { interval } \\
(\mathrm{cm})\end{array}$ & $\begin{array}{l}\text { Depth } \\
\text { (mbsf) }\end{array}$ & $\begin{array}{c}\text { Mangano- } \\
\text { siderate } \\
(2.82 \AA \\
\%)\end{array}$ & $\begin{array}{c}\text { Rhodo- } \\
\text { chrosite } \\
(2.84 \AA \\
\%)\end{array}$ & $\begin{array}{c}\text { Ca-rich } \\
\text { rhodochrosite } \\
(2.86-2.88 \AA ; \\
\%)\end{array}$ & $\begin{array}{c}\text { Calcite } \\
(3.03-3.01 \AA ; \\
\%)\end{array}$ & $\begin{array}{c}\mathrm{FeCO}_{3} \\
(\%)\end{array}$ & $\underset{(\%)}{\mathrm{MnCO}_{3}}$ & $\underset{(\%)}{\mathrm{MgCO}_{3}}$ & $\begin{array}{c}\mathrm{CaCO}_{3} \\
(\%)\end{array}$ & $\begin{array}{c}\text { Bulk } \\
\text { carbonate } \\
(\%)\end{array}$ \\
\hline $64 \mathrm{R}-1,39$ & 617.89 & 79 & 5 & 5 & 11 & 39.2 & 26.4 & 2.8 & 5.9 & 74.4 \\
\hline $64 \mathrm{R}-1,88$ & 618.37 & 66 & 3 & 3 & 28 & 29.0 & 18.7 & 2.1 & 17.8 & 67.7 \\
\hline $64 \mathrm{R}-3,64$ & 621.35 & 70 & 15 & 15 & 0 & 30.6 & 25.2 & 2.4 & 5.5 & 63.8 \\
\hline $65 \mathrm{R}-2,4$ & 628.75 & 0 & 0 & 100 & 0 & 7.5 & 51.2 & 1.5 & 11.6 & 71.9 \\
\hline $66 \mathrm{R}-1,53$ & 637.33 & 6 & 24 & 70 & 0 & 5.7 & 35.8 & 0.9 & 11.3 & 53.9 \\
\hline $66 \mathrm{R}-3,66$ & 640.46 & 7 & 29 & 54 & 10 & 6.5 & 28.2 & 1.2 & 10.8 & 46.7 \\
\hline $67 \mathrm{R}-1,124$ & 647.75 & 0 & 0 & 100 & 0 & 1.9 & 52.6 & 0.8 & 23.0 & 78.5 \\
\hline $67 \mathrm{R}-2,47$ & 648.47 & 0 & 15 & 85 & 0 & 3.4 & 50.5 & 1.5 & 22.9 & 78.4 \\
\hline $67 \mathrm{R}-2,47$ & 648.47 & 0 & 0 & 80 & 20 & n.d. & n.d. & n.d. & n.d. & 29.3 \\
\hline $67 \mathrm{R}-2,47$ & 648.47 & 0 & 0 & 24 & 76 & 2.0 & 0.9 & 0.3 & 9.4 & 12.7 \\
\hline $67 \mathrm{R}-2,95$ & 648.95 & 3 & 21 & 72 & 4 & 4.4 & 44.1 & 0.9 & 11.6 & 61.1 \\
\hline $67 \mathrm{R}-3,129$ & 650.79 & 7 & 0 & 93 & 0 & 0.9 & 47.7 & 0.9 & 7.7 & 57.3 \\
\hline $68 \mathrm{R}-2,4$ & 657.74 & 0 & 0 & 85 & 15 & 4.7 & 21.5 & 0.8 & 7.0 & 34.0 \\
\hline $68 \mathrm{R}-3,129$ & 660.49 & 0 & 0 & 0 & 100 & 6.3 & 1.4 & 1.6 & 25.5 & 34.9 \\
\hline
\end{tabular}

Note: Amounts of the four major cations expressed as carbonates calculated from chemical analysis of the bulk sample.

$\mu \mathrm{m}$. Only some biogenic tests are cemented by sparry carbonate (20-150 $\mu \mathrm{m})$, which appears to be mostly calcite.

Outside the micritic burrow fills, the authigenic carbonates consist of coarser and more idiomorphic crystals. The carbonate grains (approximately $10-50 \mu \mathrm{m}$, ranging up to $100 \mu \mathrm{m}$ in diameter) are not densely packed as they are in the burrows, but are more scattered. Therefore, a higher content of noncarbonate minerals (e.g., clay minerals) is present in these concretionary zones. Rare foraminifer tests were partly replaced by microsparry carbonate and commonly filled by sparry calcite. Most samples contain pyrite as cavity fillings, coatings on microfossils, patches, or framboids. Two samples from dark reddish layers, which owe their color to higher iron concentrations (Fig. 6) related to dispersed iron oxyhydroxides in the clay matrix, contain single rhombohedral crystals $(20-30 \mu \mathrm{m})$ of calcium-rich rhodochrosite (Pl. 4, Fig. 5).

Whereas most concretionary samples at deeper levels are texturally similar, the microtexture of the uppermost two concretion samples (105-647A-64R-1, 38-40 cm, and 105-647A-64R-1,
$85-90 \mathrm{~cm}$ ) show more complex cementation and replacement phenomena (Fig. 7). The concretions are composed mostly of carbonate spherulites having diameters of 40 to $60 \mu \mathrm{m}$ (Pl. 1, Figs. 3 and 4). They sometimes occur as isolated grains in a clay or carbonate matrix or as more closely packed aggregates showing polygonal outlines (Fig. 7B). The carbonate spherulites generally consist of an outer radially fibrous zone of calcium rhodochrosite characterized by a standing cross under crossed nicols and enclosing a dark core of fine-grained manganosiderite mud. The outer fibrous zone of the spherulites usually is replaced by coarser crystals. Opaque grains of pyrite are scattered throughout. The chemical composition of the spherulite cores is similar to that of carbonate mud of the burrow fills (Table 3 ). Both consist of manganosiderite and might have the same origin. Formation of these spherulites can be studied at the rim of the micritic burrows. A radial, relatively clear fringe cement zone of calcium-rich rhodochrosite has the same mineralogical composition as the outer fibrous zone of the spherulites. Transitions between the first generation of fringe cement and the for- 
Table 2. Bulk chemical analyses of selected samples.

\begin{tabular}{|c|c|c|c|c|c|c|c|c|c|}
\hline $\begin{array}{c}\text { Sample } \\
\text { interval } \\
(\mathrm{cm})\end{array}$ & $\begin{array}{l}\text { Depth } \\
\text { (mbsf) }\end{array}$ & $\begin{array}{c}\text { Carbonate } \\
(\%)\end{array}$ & $\begin{array}{l}P \\
(\%)\end{array}$ & $\begin{array}{c}\text { Apatite } \\
(\%)\end{array}$ & $\begin{array}{l}\mathrm{Fe} \\
(\%)\end{array}$ & $\begin{array}{l}\mathrm{Mn} \\
(\%)\end{array}$ & $\begin{array}{l}\mathrm{Mg} \\
(\%)\end{array}$ & $\begin{array}{l}\mathrm{Ca} \\
(\%)\end{array}$ & \\
\hline $62 R-2,28$ & 599.88 & 23.6 & 0.044 & 0.2 & 4.98 & 0.13 & 1.19 & 7.80 & \\
\hline $62 \mathrm{R}-3,26$ & 601.36 & 29.1 & n.d. & n.d. & 4.32 & 0.19 & 1.53 & 5.36 & \\
\hline $62 R-5,119$ & 605.29 & 33.2 & n.d. & n.d. & 2.88 & 0.22 & 1.50 & 10.98 & \\
\hline $63 \mathrm{R}-1,12$ & 607.92 & 26.7 & 0.043 & 0.2 & 5.65 & 0.19 & 1.24 & 9.96 & \\
\hline $64 \mathrm{R}-1,39$ & 617.89 & 74.4 & 0.580 & 3.1 & 16.34 & 11.19 & 2.74 & 3.42 & c \\
\hline $64 \mathrm{R}-1,48$ & 617.98 & 0.1 & 0.038 & 0.2 & 5.56 & 0.06 & 1.68 & 0.26 & \\
\hline $64 \mathrm{R}-1,88$ & 618.37 & 67.7 & 0.890 & 4.8 & 15.42 & 10.13 & 2.63 & 13.17 & c \\
\hline $64 \mathrm{R}-3,64$ & 621.35 & 63.8 & 0.464 & 2.5 & 15.40 & 12.85 & 2.79 & 3.89 & c \\
\hline $65 \mathrm{R}-1,32$ & 627.52 & 0.0 & 0.035 & 0.2 & 5.43 & 0.06 & 1.32 & 0.20 & \\
\hline $65 R-2,4$ & 628.75 & 71.9 & 0.106 & 0.5 & 3.64 & 25.21 & 1.68 & 7.84 & c \\
\hline $65 R-2,117$ & 629.85 & n.d. & 0.063 & 0.3 & 12.69 & 0.82 & 1.30 & 0.27 & \\
\hline $66 \mathrm{R}-1,53$ & 637.33 & 53.9 & 1.750 & 9.5 & 3.42 & 21.62 & 1.28 & 9.35 & c \\
\hline $66 \mathrm{R}-3,40$ & 640.21 & 10.6 & 0.027 & 0.1 & 4.54 & 0.10 & 1.53 & 3.42 & \\
\hline $66 \mathrm{R}-3,66$ & 640.46 & 46.7 & 1.316 & 7.1 & 3.13 & 13.77 & 1.29 & 7.22 & c \\
\hline $67 \mathrm{R}-1,124$ & 647.75 & 78.5 & 0.122 & 0.6 & 1.03 & 27.78 & 1.02 & 16.64 & $\mathrm{c}$ \\
\hline $67 R-2,47$ & 648.47 & 78.4 & 0.104 & 0.5 & 1.81 & 27.60 & 1.95 & 17.19 & $c c$ \\
\hline $67 R-2,47$ & 648.47 & 29.3 & 1.935 & 10.5 & n.d. & n.d. & n.d. & n.d. & $\mathrm{rc}$ \\
\hline $67 R-2,47$ & 648.47 & 12.7 & 2.865 & 15.5 & 2.62 & 1.29 & 0.93 & 17.02 & oc \\
\hline 67R-2, 89 & 648.89 & 14.9 & 0.016 & 0.1 & 5.19 & 0.11 & 1.73 & 4.65 & \\
\hline $67 R-2,95$ & 648.95 & 61.1 & 0.155 & 0.8 & 1.88 & 19.14 & 0.91 & 6.93 & c \\
\hline $67 \mathrm{R}-3,129$ & 650.79 & 57.3 & 0.112 & 0.6 & 0.53 & 28.57 & 1.16 & 6.36 & c \\
\hline $68 \mathrm{R}-1,95$ & 657.15 & n.d. & 0.036 & 0.2 & 4.85 & 0.12 & 1.14 & 2.59 & \\
\hline $68 \mathrm{R}-2,4$ & 657.74 & 34.0 & 1.378 & 7.5 & 2.75 & 12.86 & 1.11 & 5.78 & c \\
\hline $68 \mathrm{R}-3,129$ & 660.49 & 34.9 & 0.098 & 0.5 & 2.03 & 0.46 & 1.23 & 11.50 & c \\
\hline $68 \mathrm{R}-4,2$ & 660.72 & 17.3 & 0.057 & 0.3 & 2.35 & 0.18 & 1.19 & 5.77 & \\
\hline $68 \mathrm{R}-4,113$ & 661.83 & n.d. & 0.042 & 0.2 & 3.93 & 0.20 & 1.22 & 5.98 & \\
\hline $70 \mathrm{R}-2,133$ & 688.03 & n.d. & 0.033 & 0.2 & 1.63 & 0.19 & 0.90 & 12.71 & \\
\hline $71 \mathrm{R}-1,30$ & 695.11 & 27.1 & 0.032 & 0.2 & 3.02 & 0.12 & 1.82 & 8.87 & \\
\hline
\end{tabular}

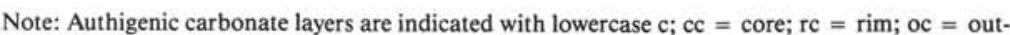
side of concretion. Apatites are calculated from phosphorus concentrations.

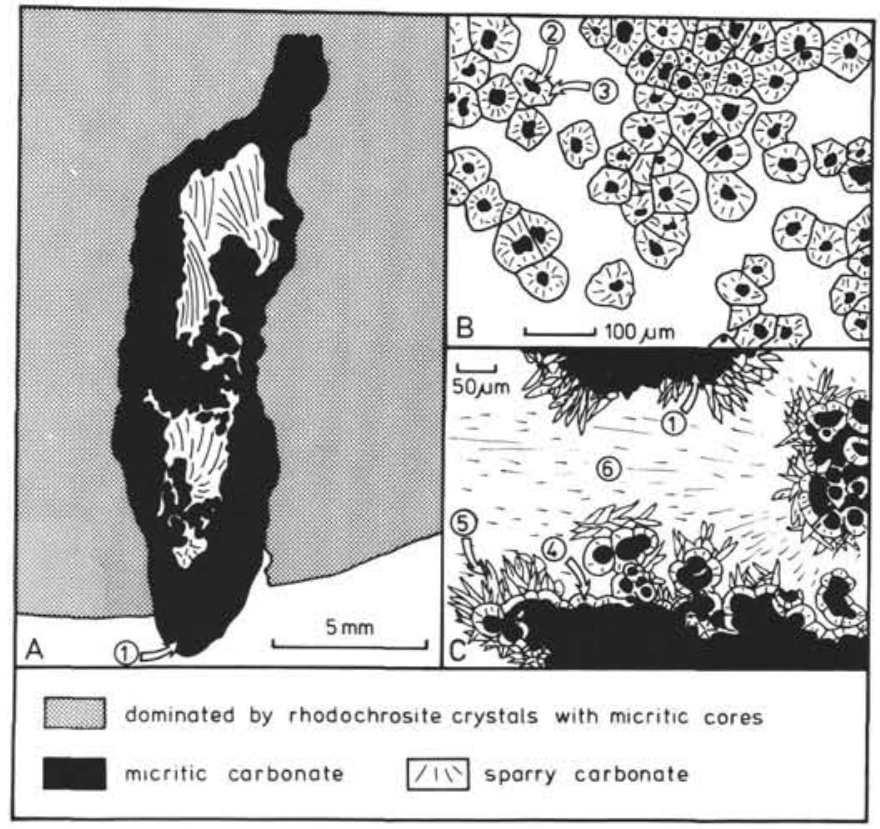

Figure 7. Schematic drawings from a thin section of Sample 105-647A$64 \mathrm{R}-1,85-90 \mathrm{~cm}$ (numbers give examples for position of microprobe analyses, listed in Table 3). A. Micritic vertical burrow with internal patches of sparry carbonate surrounded by large domains where spherulites and replaced spherulites dominate. B. Detail from sediment surrounding the burrow. Calcium-rich rhodochrosite crystals with micritic core (2) of manganosiderite show partly polygonal outlines and sometimes internal spherulitic structures. C. Detail of sparry patches in the burrow show transitions to the spherulites, a clear fringe cement zone of calcium-rich rhodochrosite (4), needle-cement of siderite crystals (5), and void-filling sparry calcites (6). mation of the spherulites can be observed. The fringe cement shows partly a "medium dust line" produced by small inclusions, representing zonar building of the crystals.

A second generation of carbonate cement in the sparry patches of the burrow fills is represented by 50 - to 100 -m-long prismatic siderite needles (Table 3; Fig. 7) growing in part on the fringe cement and sometimes directly on the micritic manganosiderite. A third group of sparry carbonate is composed of coarse-grained blocky to partly radiaxial fibrous calcite having crystal lengths up to $200-300 \mu \mathrm{m}$. This type of sparry calcite has the largest crystal grain diameters and seems to fill the remaining void domain in the burrow.

\section{Occurrence and Preservation of Biogenic Constituents}

In the investigated sediment section, biogenic carbonate components are represented by calcareous nannofossils and, to a lesser extent, by planktonic foraminifers. The concentrations are reflected by the general carbonate content (Fig. 8), excluding values from carbonate concretionary zones. The carbonate content generally correlates with the amount of planktonic foraminifers (Fig. 8) counted in the coarse fraction. Benthic fauna of the coarse fraction from Cores 105-647A-64R through 105$647 \mathrm{~A}-68 \mathrm{R}$ is dominated by arenaceous foraminifers (see Kaminsky et al., this volume). Assuming that the ratio of benthic to planktonic foraminifers $(\mathrm{B} / \mathrm{P})$ was originally similar throughout the section studied, large shifts to high ratios in Cores 105647A-64R through 105-647A-68R may have resulted from strong carbonate dissolution. The carbonate dissolution zone thus defined (Cores 105-647A-64R through 105-647A-68R) is documented by carbonate contents lower than in the levels below and above. The lowest carbonate concentrations were measured in Cores 105-647A-64R and 105-647A-65R, which coincides with the highest dissolution intensities derived from $\mathrm{B} / \mathrm{P}$ ratios (about 70-80; Fig.8).

The second group of biogenic constituents consists of siliceous microfossils found only in a few samples. SEM and thin- 
Table 3. Bulk chemical analyses of different authigenic carbonate minerals from Sample 105-647A-64R-1, 85-90 cm.

\begin{tabular}{|c|c|c|c|c|c|}
\hline Occurrence & $\begin{array}{l}\mathrm{MnCO}_{3} \\
(\%)\end{array}$ & $\begin{array}{l}\mathrm{FeCO}_{3} \\
(\%)\end{array}$ & $\underset{(\%)}{\mathrm{CaCO}_{3}}$ & $\underset{(\%)}{\mathrm{MgCO}_{3}}$ & Name of mineral \\
\hline $\begin{array}{l}\text { 1) Carbonate matrix } \\
\text { of burrow fills }\end{array}$ & 34 & 43 & 12 & 11 & Manganosiderite \\
\hline $\begin{array}{l}\text { 2) Mud core of the } \\
\text { spherulites }\end{array}$ & 34 & 43 & 12 & 11 & Manganosiderite \\
\hline $\begin{array}{l}\text { 3) Outer fibrous zone } \\
\text { of spherulites }\end{array}$ & 75 & 1 & 19 & 5 & $\begin{array}{l}\text { Calcium-rich } \\
\text { rhodochrosite }\end{array}$ \\
\hline $\begin{array}{l}\text { 4) Fringe cement } \\
\text { (first generation) }\end{array}$ & 77 & 1 & 17 & 5 & $\begin{array}{l}\text { Calcium-rich } \\
\text { rhodochrosite }\end{array}$ \\
\hline $\begin{array}{l}\text { 5) Needle cement } \\
\text { (second generation) }\end{array}$ & 15 & 55 & 14 & 16 & Siderite \\
\hline $\begin{array}{l}\text { 6) Radiaxialfibrous } \\
\text { void-filling cement } \\
\text { (third generation) }\end{array}$ & 4 & 5 & 90 & 1 & Calcite \\
\hline
\end{tabular}

Note: Examples for detected positions (1-6) are shown in Figure 7.

section observations indicate that siliceous tests are rare outside of the concretionary zones. Two samples (105-647A-64R-1, 95 $\mathrm{cm}$; 105-647A-66R-3, $70 \mathrm{~cm}$ ) each contain one diatom remnant preserved as a strongly dissolved opal-A skeleton (Bohrmann and Stein, this volume).

However, analysis of carbonate concretionary zones shows that diatoms and radiolarians were originally present to much greater extent. Many ghost structures from siliceous biogenic skeletons were found in the lithified burrow fills. These ghosts are embedded in a fine-grained carbonate matrix that reveals structural details of radiolarian tests and diatom valves. For ex- ample, the very fine sieve membranes of diatom frustules are preserved as casts by authigenic smectites (Plate 4, Fig. 3). Biogenic opal-A is no longer present, and all skeletons are replaced completely by smectites (Pls. 2 and 3). Well-developed smectites form a densely intergrown authigenic fabric, which, for example, is so compact that radiolarian pseudomorphs could be isolated by leaching the carbonate with hydrochloric acid and sieving (Pl. 3, Figs. 1, 3, and 4).

Other biogenic constituents in the coarse-fraction samples include phosphatic fragments such as fish bones or remnants of crustaceans. One thin section (105-647A-67R-2, $47 \mathrm{~cm}$ ) from a carbonate concretionary zone shows a cross section through an entire shell of a well-preserved crustacean, which is embedded in the micritic matrix (Pl. 4, Fig. 4).

\section{Authigenic Noncarbonate Minerals}

Clay minerals are the major sediment constituents throughout lithologic Unit IV. The composition of the carbonate-free clay mineral assemblage was analyzed by X-ray diffraction. Smectites are the major clay minerals making up between $70 \%$ and $98 \%$ (but mostly more than $90 \%$ ) of the $<2 \mu$ m fraction (Fig. 9). Chlorite is present only as a trace mineral (up to approximately $1 \%$ ). Kaolinite and illite reach concentrations from $10 \%$ to $30 \%$ in two samples of Core 105-647A-65R (Fig. 9).

In numerous sediment samples most of the clay mineral textures contain authigenic fabrics. Smectites occur as ragged-edged flakes growing in the pore space between other grains (Plate 5, Fig. 3) or as cements growing in larger cavities, such as in biogenic tests (Pl. 5, Figs. 1, 2, and 4). Replacement of siliceous

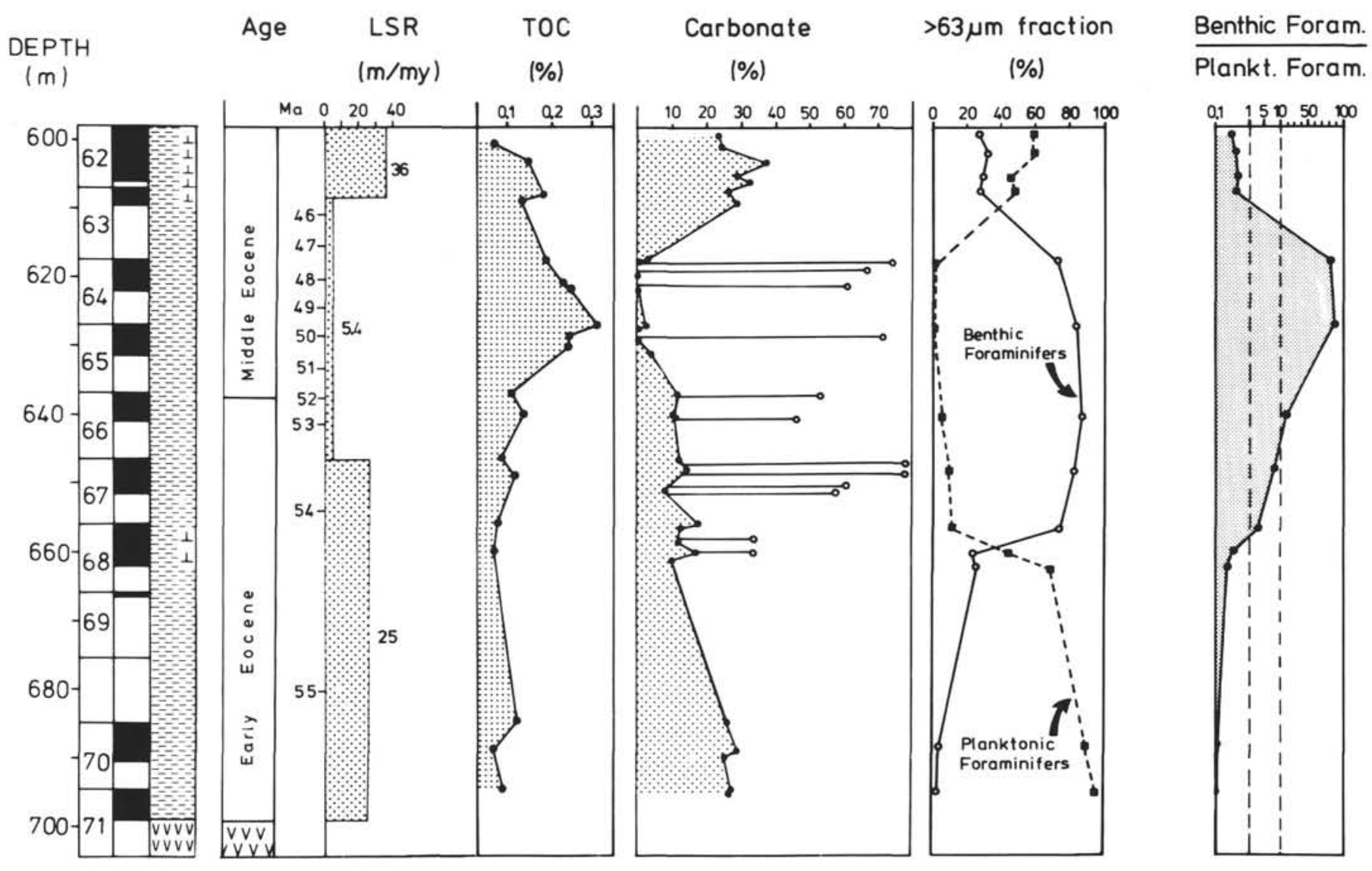

Figure 8. Stratigraphy and linear sedimentation rates (LSR) calculated from age-depth data (after Srivastava, Arthur, et al., 1987), amounts of benthic and planktonic foraminifers from the coarse fraction, and the ratio of both in comparison with the carbonate values. TOC $=$ total organic carbon. 


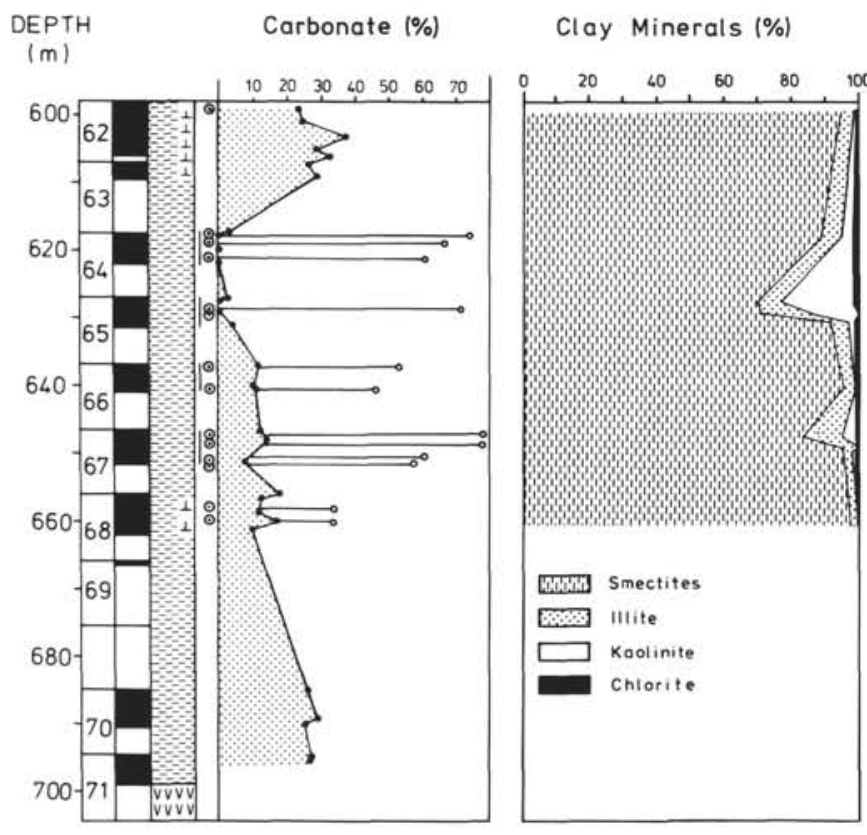

Figure 9. Clay mineral distribution in the carbonate-free fraction.

skeletons by smectites in the carbonate concretions was outlined above.

XRD analyses from the clay-mineral fraction show two (060) reflection peaks at 1.503 and $1.498 \AA$, after calibration with the (211) quartz peak at $1.541 \AA$, which indicates dioctahedral smectites. EDAX-spectra indicate that aluminum and iron contents exceed magnesium contents, which also is typical for dioctahedral smectites. However, aluminum and iron concentrations vary, which indicates different chemical compositions between aluminum-rich (beidellitic) and iron-rich (nontronitic) smectites. Pure end-members were not found.

Numerous SEM observations of carbonate concretionary layers reveal the common occurrence of apatite as small single crystals, twins, and radiating aggregates. The idiomorphic crystals (Pl. 4, Figs. 1 and 2) have a typical hexagonal shape and are approximately $2 \mu \mathrm{m}$ long and $0.4 \mu \mathrm{m}$ in diameter. Authigenic apatites were observed to grow on the surface of carbonate crystals. $\mathrm{X}$-ray diffraction analysis of apatite-rich samples confirm that the apatites are fluorapatites or hydroxyapatites. Detection of such apatites was unexpected because in the marine environment carbonate apatite is the common apatite phase (Baturin, 1982). Claystone samples from the vicinity of the authigenic carbonates do not contain apatite crystals.

To examine quantitative patterns of apatite precipitation, we measured phosphorus contents in both claystone samples and carbonate concretions. Phosphorus concentrations range widely but show an interesting distribution pattern (Fig. 10, Table 2). The phosphorus content in claystone lithologies ranges between $0.016 \%$ and $0.063 \%$, with an average value of $0.038 \%$. Phosphorus concentrations in carbonate concretionary zones are considerably higher, ranging between $0.1 \%-2.8 \%$. Assuming that phosphorus is included mainly in the newly precipitated apatite, the amount of apatite $\mathrm{Ca}_{5}\left[(\mathrm{~F}, \mathrm{OH}) /\left(\mathrm{PO}_{4,3}\right)\right]$ may be calculated for the bulk samples (Table 2). Calculated apatite concentrations in concretionary zones range between $0.5 \%$ and $15.5 \%$.

Apatite amounts (Table 2) greater than $4 \%-5 \%$ were also recognized in X-ray diffractograms run for carbonate mineralogy in the $30-38^{\circ} 2 \theta \mathrm{CoK}_{\alpha}$ interval. Apatite was identified by a typical double peak at 2.800 and $2.772 \AA$. Peak intensities are in good agreement with apatite contents calculated from chemical analyses.
Other authigenic minerals observed in the section are iron oxyhydroxides in the reddish layers and pyrite in the grayishgreen lithologies. Although smectites contain a certain amount of iron, X-ray records show that the iron concentrations measured for the claystone samples (Fig. 6) reflect dominantly the occurrence of iron minerals. The iron concentrations are high (up to $12 \%-13 \%$ ) in the dark reddish layers. Where pyrite is present, the iron contents vary between $2 \%$ and $6 \%$.

In Sample 105-647A-64R-1, 85-90 cm, veins of barite were observed (Pl. 1, Fig. 1) under the SEM (EDAX: barium and sulfur).

\section{DISCUSSION}

\section{Iron and Manganese Accumulation}

The dark reddish and greenish-gray beds found in Cores $105-$ 647A-64R through 105-647A-68R alternate with thicknesses of approximately $10-70 \mathrm{~cm}$ and indicate changes in sedimentary environment. Iron-rich red layers begin $60 \mathrm{~m}$ above oceanic basement over a sequence of nannofossil-bearing claystones. Dark red beds containing higher amounts of iron (up to $12 \%$ $13 \%$; Fig. 6) may form during periods when sedimentation rates are low as a dissolution residue at a hiatus. Because numerous red layers occur, we do not think it reasonable that the sedimentation rates have changed repeatedly in this claystone environment. According to shipboard data (Srivastava, Arthur, et al., 1987), stratigraphic control is well established above Core 105647A-63R and also in Cores 105-647A-67R through -71R, which indicates Linear Sedimentation Rates (LSR) of 36 and $25 \mathrm{~m} /$ m.y. (Fig. 8). In Cores 105-647A-63R through -66R, no biostratigraphic data were available, and an LSR of $5.4 \mathrm{~m} / \mathrm{m}$.y. was calculated for this interval. The low average sedimentation rate established for this $35-\mathrm{m}$ interval most probably includes a hiatus. However, red beds start $20 \mathrm{~m}$ below this interval in Core $105-647 \mathrm{~A}-68 \mathrm{R}$, where stratigraphic data do not indicate the presence of a hiatus.

Sediments also may be enriched in iron supplied from a hydrothermal source. We do not believe that direct precipitation from hydrothermal fluids occurred at this location because we did not find the mineral assemblages typical of higher-temperature environments. A more likely source for the iron (and probably manganese oxyhydroxides) is indirect supply from a hydrothermal source. In the highly oxidizing environment of seawater, iron and manganese from hydrothermal fluids form oxyhydroxide flocs that can be transported easily by bottom currents. For example, in the Southeast Pacific, amorphous oxyhydroxide flocs are formed at the crest of the East Pacific Rise, are transported by bottom currents, and become ponded in depressions, for example. in the Bauer Deep (Dymond and Veeh, 1975; Heath and Dymond, 1977; Cole, 1985). A similar mechanism could have been responsible for iron-enrichment zones in the early/middle Eocene of the Labrador Sea. At that time, the active Labrador Sea midocean ridge was located at a distance of approximately $100 \mathrm{~km}$ from Site 647 . Iron and manganese oxyhydroxides, formed by hydrothermal fluids at the ridge crest or in another area of volcanic activity, may have been transported as flocs and accumulated in seafloor depressions. Cyclicity of iron enrichments could be explained by variations in supply of iron oxyhydroxides caused by changes in bottom-water flow or volcanic activity. However, on the basis of other geochemical criteria, Arthur et al. (this volume) reject a major influence of hydrothermal source in Unit IV.

\section{Smectite Formation}

The occurrence of siliceous microfossils in the lithified burrows contrasts with the almost complete absence of siliceous mi- 


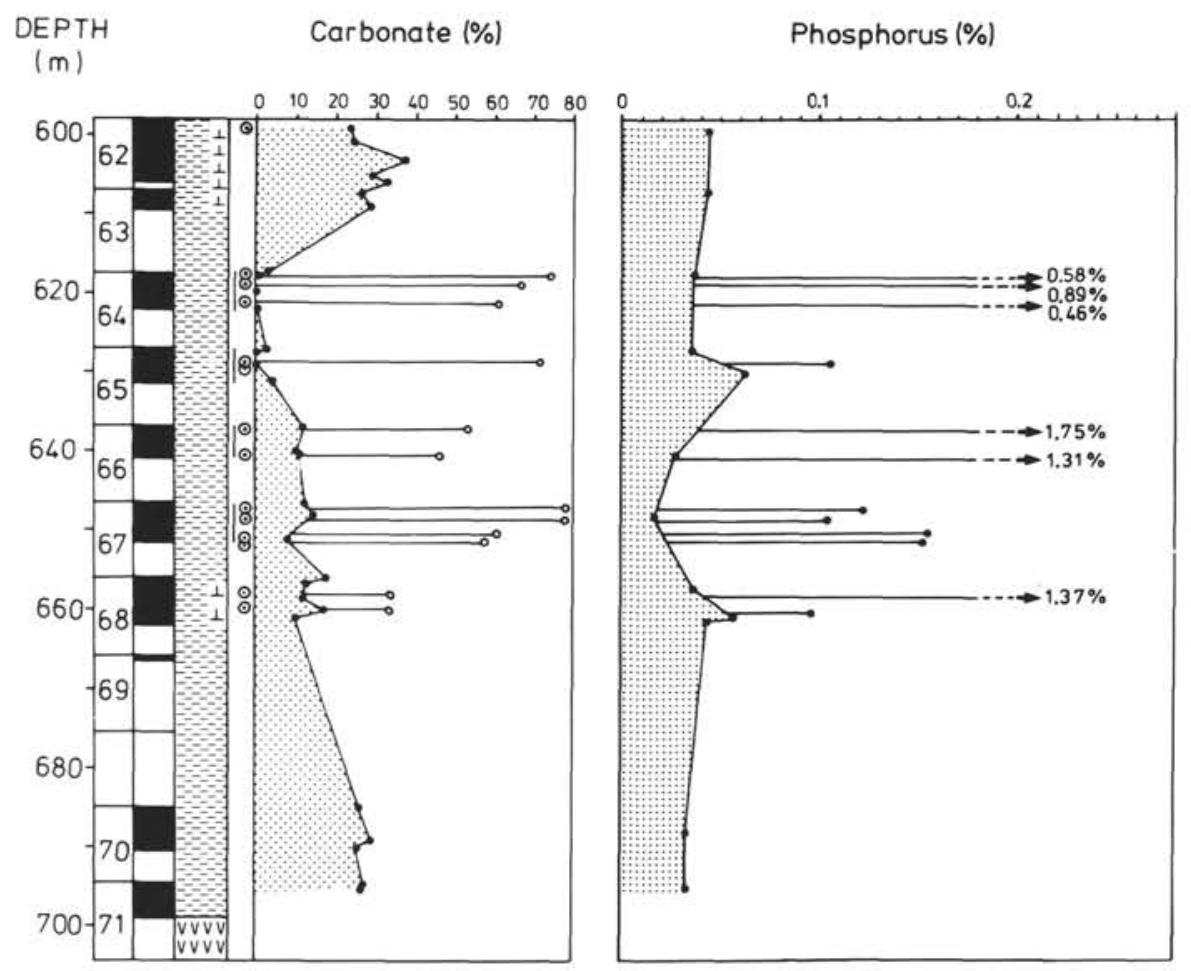

Figure 10. Concentrations of phosphorus from the investigated interval. Values from authigenic carbonates are connected by horizontal lines with the background values from the claystones.

crofossils outside the burrows. Diatom frustules and radiolarians are preserved as well-developed smectite crystals embedded in authigenic carbonate. Details of the frustule morphology indicate that authigenic carbonates precipitated when the siliceous skeletons were still preserved as opal-A tests. After cementation of siliceous skeletons in the burrows by carbonates, radiolarian tests and diatom frustules were converted to smectites having varying iron and aluminum content.

The following mechanisms have been postulated for formation of authigenic smectites in deep sea sediments (Hein et al., 1979b; Cole and Shaw, 1983):

1. Smectites may precipitate directly from hydrothermal fluids.

2. Authigenic smectites may form by alteration of volcanic rock fragments and glass or they may precipitate from solutions in basalt cavities at low temperature.

3. Smectites may form from the low-temperature combination of iron oxyhydroxide and biogenic silica (Heath and Dymond, 1977; Cole and Shaw, 1983; Cole, 1985).

Replacement of siliceous skeletons by smectite minerals in the investigated Eocene section of Labrador Sea strongly suggests the latter mode of smectite formation. Volcanic rock fragments and glass were not found and thus do not seem to be responsible for smectite growth. Direct precipitation from hydrothermal fluids also can be excluded.

Formation of authigenic iron-rich smectite by low-temperature combination of iron oxyhydroxide and biogenic silica is described from the DOMES area in the north equatorial Pacific manganese nodule belt (Hein et al., 1979b) and from the Bauer Deep of the eastern equatorial Pacific (Heath and Dymond, 1977; Cole and Shaw, 1983; Cole, 1985). According to Hein et al. (1979a), authigenic smectites probably form in large areas of the North Pacific from the combination of iron oxyhydroxides produced at the East Pacific Rise, from silicon and aluminum released from biogenic silica, and perhaps additional aluminum from an external source (e.g., river supply). The chemistry of the smectites varies corresponding to the distance from the source of iron. Near the location where iron oxyhydroxide is generated, high iron and low aluminum smectites were found (Heath and Dymond, 1977; Cole, 1985), whereas at greater distances smectites have moderate iron and aluminum contents (Hein et al., 1979b).

Semiquantitative estimates by EDAX-spectra showed that the chemistry of the Labrador Sea smectites varies from aluminumrich to iron-rich, while no pure end-members (beidellite or nontronite) were observed. Compositional variation may be explained by different supply rates of iron oxyhydroxides and biogenic opal.

Predominance of smectite in the clay-mineral assemblage (Fig. 9; see also Nielsen et al., this volume) implies that authigenic smectite formation by low temperature combination of iron oxyhydroxide and biogenic silica was probably widespread during the Eocene in the Labrador Sea. Assuming that this process occurred in the whole section, biogenic opal was nearly completely converted to smectite. In the burrows, where carbonate cementation occurred early, opal skeletons also are converted to smectite, but the morphology of diatoms and radiolarians is nonetheless well preserved.

The possibility that part of the smectite minerals is terrigenous in origin cannot be excluded. However, observations with the SEM (PI. 5) show that the smectites usually have grown insitu (or at least have continued to grow in-situ). Therefore, we assume that the dominant part of the smectites is of authigenic origin. Other clay minerals such as illite, kaolinite, and traces of chlorite are of detrital origin and are probably concentrated in sediment sections of lower sedimentation rates. Nonsmectite clay-mineral enrichments are documented in Core 105-647A65R (Fig. 9). This agrees with data of Nielsen et al. (this vol- 
ume) showing $30 \%$ nonsmectite clay minerals in the same core and also an additional enrichment in Core 105-647A-64R with more than $60 \%$ illite and kaolinite.

\section{Formation of Authigenic Carbonates}

Diagenetic processes in the investigated sediment section are further documented by the occurrence of concretions composed of complex authigenic carbonates having diverse microtextures. According to $\delta^{13} \mathrm{C}$ values, Tassé and Hesse (1984) suggested that the formation of manganese- and iron-rich carbonates from Cretaceous deep-sea sediments of the Western Alps took place in greater burial depths, in the methane generation zone.

Similar depths were described by von Rad and Botz (1987) for the formation of siderite and manganosiderite at DSDP Site 603. Formation of these carbonates at such levels requires deep mobilization of manganese and iron. Manganese and iron could be released by different processes, e.g., opal-A dissolution (Gieskes, 1981), alteration of volcanic debris (Hein et al., 1979a) or other diagenetic reactions. The carbonate concretions from ODP Site 647 today are found between $617-660 \mathrm{mbsf}$, but various features suggest early formation at much shallower burial depths.

Based on macroscopic examinations and thin section observations, two generations of carbonate precipitates can be distinguished. Fine-grained micritic burrow fills represent the earliest generation of carbonates. They project into the surrounding sediments. Original plane bedding structures above and below the concretions show numerous phenomena of deformation. Outside the concretions compaction structures, such as flattened burrows and crushed microfossils, are well documented. Within the concretions uncollapsed foraminifers are filled with sparry calcite. These structures indicate that lithification of the burrows took place before compaction and lithification of the surrounding claystones.

As discussed above, precipitation of calcium-rich rhodochrosite in burrows took place before smectite formation. Smectite precipitation by low-temperature combination of iron oxyhydroxide and biogenic opal was observed in the Bauer Deep at 20-40 $\mathrm{cm}$ below the seafloor (Cole, 1985). According to Cole, initial formation of amorphous smectite should occur under oxidizing conditions, which, if aged under reducing conditions, should develop into crystalline smectites. However, Harder (1976) could only synthesize iron-rich smectites at low temperatures from hydroxides and silica under reducing conditions in the presence of $\mathrm{Fe}^{3+}$. In the Eocene Labrador Sea slightly reducing conditions also are required for smectite formation because of the previous manganese-rich carbonate precipitation in the burrow structures. Early manganese carbonate formation is favored in mildly reducing or postoxic environments (Berner, 1981), where pore water contains neither oxygen nor sulfide. From studies of North Atlantic piston cores, Thomson et al. (1986) proposed that manganese oxyhydroxide reduction and manganese carbonate formation are completed in a narrow layer below the oxidation zone. Based on thermodynamic solubility calculations and mineralogical determinations, Pedersen and Price (1982) found a common association between manganese carbonate precipitation and coarser-grained sediments. This phenomenon could explain why the precipitation of carbonate occurs in burrow structures, where coarser-grained sediment components could be accumulated by burrowing activity of organisms. Other explanations for preferential carbonate precipitation invoke chemical microenvironments produced by slight changes, e.g., in organic matter content.

Outside the micritic burrow fills, authigenic carbonates have larger grain size $(10-100 \mu \mathrm{m})$ and are not as densely packed. These carbonate precipitates do not contain "ghosts" of siliceous microfossils, indicating that they formed after biogenic opal already had been converted to smectite. Thin section inves- tigations show that these later authigenic carbonates are characterized by concretionary growth mostly around an early cemented burrow fill (Fig.4), with decreasing density of calciumrich rhodochrosite crystals toward the rim. However, the calcite content increases outward from the concretion center, indicating that calcite could be the latest precipitation.

An important question concerns the source of $\mathrm{CO}_{2}$ for the carbonate concretions. The generally low TOC values (less than $0.3 \%$, even less than $0.2 \%$ in this interval; Fig. 8 ) make an organic-matter source of $\mathrm{CO}_{2}$ unlikely. We believe that the $\mathrm{CO}_{2}$ source for authigenesis of carbonates is derived from preexisting carbonate shells. Strong dissolution of biogenic carbonate is detected by the high ratio of benthic to planktonic foraminifers (Fig. 8) and may provide suitable $\mathrm{CO}_{2}$ in the sedimentary environment. This also is confirmed by stable-isotope data (Bohrmann et al., unpublished data), giving $\delta^{13} \mathrm{C}$ values near zero, which is typical for biogenic carbonate. However, Arthur et al. (this volume) found more negative $\delta^{13} \mathrm{C}$ values for similar concretions in the upper portion of Unit IV and attributed these to oxidized organic matter $\mathrm{CO}_{2}$ source associated with the reduction of manganese and iron.

Microprobe analyses show that the chemistry of the calciumrich rhodochrosites (with the exception of Core 105-647A-64R) varies only slightly, both in case of the early burrow fills and the later coarser carbonate grains. For most of the sediment section, this finding indicates uniform pore-water chemistry. Ironrich carbonate minerals are rare, except in Core 105-647A-64R. Iron minerals preserved as ferric oxides are responsible for the intense dark red color in numerous layers. These ferric oxides are not reduced because of the lack of sufficient reducing agent (low TOC values, Fig. 8). Small amounts of reduced $\mathrm{Fe}^{2+}$ are precipitated as sulfidic minerals in the greenish-gray lithologies and only rarely as iron carbonates, whereas manganese carbonates occur throughout.

\section{Manganosiderite and Formation of Cements}

Special chemical conditions controlled the carbonate precipitation in Core 105-647A-64R, where manganosiderite is the major carbonate phase. During periods with lower sedimentation rates, more $\mathrm{Fe}^{2+}$ could be mobilized. Elevated $\mathrm{Fe}^{2+}$ content in pore water influenced the chemistry of carbonate precipitation. Fine-grained manganosiderite formed in burrows (Pl. 1, Fig. 1; Fig. 7) as well as in the sediment and later grow into spherulites.

We found it difficult to interpret the large sparry patches in the center of a burrow (Fig.7). The question is whether it is a remaining primary or a secondary cavity space that makes up different generations of cementation in the early lithified burrow or whether it is a replacement domain with several phases of neomorphism. Dispersed inclusions, such as clay minerals, organic matter, or other authigenic minerals like pyrite, in the sparry carbonate may be evidence that the sparry domain is a replacement zone. However, the relicts are concentrated between the crystals, whereas the crystals themselves are more or less clear, which is more typical of cement formation. Clearly defined generations of crystal precipitation and the fact that freegrowing crystal faces developed without competition from adjacent crystals are additional evidence for cementation.

Assuming that the sparry patches grew as cements, large cavities must have developed by dissolution of the early lithified burrow. Dissolution most probably occurred during formation of a hiatus. The cavity was initially cemented by a calcium-rich rhodochrosite fringe cement and needle-shaped crystals of siderite. These two carbonate minerals can partly be derived from further dissolution of the manganosiderite. Because they have the same chemical composition, the outer fibrous zone of the spherulites probably grew at the same time as the fringe cement. A similar spherulitic growth of manganese carbonates having 
the same shape and size of grains is described by Pedersen and Price (1982) in deep-sea sediments from the Panama Basin.

The remaining cavity space, representing the greatest portion of the secondary cavity, was cemented later during burial by coarse-grained calcite crystals. In general, the occurrence of manganosiderite, combined with the observed complex events of precipitation in large dissolution cavities, appears to be controlled by very low sedimentation rates or a hiatus in Core 105647A-64R. Carbonate dissolution, indicated by the high ratio of benthic to planktonic foraminifers in Cores 105-647A-64R and $65 \mathrm{R}$ and the low carbonate contents (Fig. 8), are further indications of a hiatus.

\section{Apatite Precipitation}

A post-carbonate precipitation phase is represented by the authigenesis of disseminated apatite crystals. According to SEM examinations and phosphorus measurements (Fig. 10), the apatite is enriched in the carbonate concretionary zones.

Stumm and Morgan (1970) and Stumm and Leckie (1970) demonstrated experimentally that the surface of calcite acts as a favored site for apatite crystallization, with apatite crystals growing epitaxially on calcites. X-ray diffractograms of Sample 105647A-67R-2, $47 \mathrm{~cm}$ (Fig. 4) show the relationship between the amount of calcite and apatite. However, the generally greater amount of phosphorus (Fig. 10) in all concretionary layers, notably also in samples where calcite was not detected, indicates that the complex iron-, manganese-, and calcium-rich carbonates also provided suitable nucleation sites for apatite crystallization. In the carbonate concretionary zones, not only carbonate was diagenetically concentrated, but also apatite, which precipitated from dissolved $\mathrm{Ca}^{2+}$ and $\mathrm{PO}_{4}^{3+}$. Dissolved phosphate may be derived by decomposition of organic matter and reduction of iron oxyhydroxides or by dissolution of bone detritus (Baturin, 1982; Burnett, 1977). Although several phosphatic test remains were found in the coarse fraction, we consider it is more likely that iron oxyhydroxides and probably small amounts of organic matter (both subject to decay under reducing conditions) supplied the pore water with phosphorus ions.

\section{CONCLUSIONS}

1. Authigenic carbonate minerals in the Eocene lithologic Unit IV of Site 647 have a complex composition consisting predominantly of manganese-rich carbonates. Identified minerals include: calcium-rich rhodochrosite, rhodochrosite, manganosiderite, siderite, and calcite.

2. The complex carbonates derived their ions from pore solutions containing significant amounts of manganese and iron. Both elements probably were derived from a hydrothermal source on the adjacent active Labrador Sea mid-oceanic ridge. The Eocene ridge crest was situated approximately $100 \mathrm{~km}$ from Site 647. Calcium and part of the $\mathrm{CO}_{2-}$ may have been derived from dissolution of carbonate fragments. Evidence for carbonate dissolution is present in Cores 105-647A-64R through -68R, especially in Cores 105-647A-64R and -65R.

3. Iron-rich carbonates occur almost exclusively at $620 \mathrm{mbsf}$ in Core 105-647A-64R. We believe that extensive cementation in secondary cavities at the same depth is related to very low sedimentation rates and/or an interval of hiatuses at this level.

4. "Ghost" structures of siliceous biogenic components and smectite replacements of detailed biogenic opaline structures in early cemented burrows suggest originally higher amounts of biogenic opal. Replacement of biogenic opal by authigenic smectite is reflected in high smectite concentration in the clay-mineral assemblage.

5. The diagenetic sequence may be generalized as follows. Soon after deposition, some burrows were filled with micritic carbonate. Afterward, biogenic opal was transformed to smec- tites. A second phase of carbonate growth followed, producing coarser authigenic carbonate grains. Authigenic apatites, nucleating on the carbonates, represent the latest generation of precipitation.

\section{ACKNOWLEDGMENTS}

This study was supported by the "Deutsche Forschungsgemeinschaft" (Grant Th200/3/2-4). We thank P. Stoffers, R. Mühe, R. Henrich, T. Wolf, S. Pfirman, K.-H. Baumann, and the reviewers for critical remarks and discussion. XRD analyses were conducted by $\mathrm{H}$. Lange and W. Vorwerk. We also thank C. Saintlebka and R. Reimann for operating the SEM and F. Mader and D. Ackermand for microprobe analyses. We are grateful to U. Drechsler, A. Schröder, and A. Dettmer for technical assistance. The photographic work of U. Schuldt, S. Perbandt, and B. Hecht is gratefully acknowledged.

\section{REFERENCES}

Baturin, G. N., 1982. Phosphorites on the seafloor, origin, composition and distribution. Developments in Sedimentol., 33:1-343.

Berner, R. A., 1981. A new geochemical classification of sedimentary environments. J. Sediment. Petrol., 51:359-365.

Burnett, W. C., 1977. Geochemistry and origin of phosphorite deposits from off Peru and Chile. Geol. Soc. Am. Bull., 88:813-823.

Cole, T. G., 1985. Composition, oxygen isotope geochemistry and origin of smectite in the metalliferous sediments of the Bauer Deep, Southeast Pacific. Geochim. Cosmochim. Acta, 49:221-235.

Cole, T. G., and Shaw, H, F., 1983. The nature and origin of authigenic smectite in some recent marine sediments. Clay Minerals, 18:239252.

Dymond, J., and Veeh, H. H., 1975. Metal accumulation rates in the southeast Pacific and the origin of metalliferous sediments. Earth Planet. Sci. Lett., 28:13-22.

Gieskes, J. M., 1981. Deep-sea drilling interstitial water studies: implications for chemical alteration of the oceanic crust, layers 1 and 2. Soc. Econ. Petrol. Mineral. Spec. Publ., 32:149-167.

Goldsmith, J. R., and Graf D. L., 1958. Relation between lattice constants and composition of the Ca-Mg carbonates. Am. Mineral., 43: 84-101.

Harder, H., 1976. Nontronite synthesis at low temperatures. Chem. Geol., 18:169-180.

Heath, G. R., and Dymond, J., 1977. Genesis and transformation of metalliferous sediments from the East Pacific Rise, Bauer Deep, and Central Basin, northwest Nazca Plate. Geol. Soc. Am. Bull., 88: 723-733.

Hein, J. R., O'Neil, J. R., and Jones, M. G., 1979a. Origin of authigenic carbonates in sediment from the deep Bering Sea. Sedimentology, 26:681-705.

Hein, J. R., Yeh, H.-S., and Alexander, E., 1979b. Origin of iron-rich montmorillonite from the manganese nodule belt of the North Equatorial Pacific. Clays and Clay Minerals, 27(3):185-194.

Henrich, R., in press. Diagenetic environments of authigenic carbonates and opal-CT crystallization in the lower Miocene to Oligocene sediments of Site 643. In Eldholm, O., Thiede, J., et al., Proc. ODP, Sci. Results, 104: College Station, TX (Ocean Drilling Program).

Kelts, K., and McKenzie, J. A., 1982. Diagenetic dolomite formation in Quaternary anoxic diatomaceous muds of Deep Sea Drilling Project Leg 64, Gulf of California. In Curray, J. R., Moore, D. G., et al., Init. Repts. DSDP, 64: Washington (U. S. Govt. Printing Office), 553-569.

Lange, H., 1982. Distribution of chlorite and kaolinite in eastern Atlantic sediments of North Africa. Sedimentology, 29:427-431.

Matsumoto, R., and Matsuhisa, Y., 1983. Chemistry, carbon and oxygen isotope ratios, and origin of deep-sea carbonates at Sites 438, 439, and 584: Inner slope of the Japan Trench. In Kagami, H., Karig, D. E., Coulbourn, W. T., et al., Init. Repts. DSDP, 87: Washington (U.S. Govt. Printing Office), 669-678.

Okada, H., 1980. Pebbles and carbonate nodules from Deep Sea Drilling Project Leg 56 cores. In Scientific Party, Init. Repts. DSDP, 56: Washington (U.S. Govt. Printing Office), 1089-1105.

Pedersen, T. F., and Price, N. B., 1982. The geochemistry of manganese carbonate in Panama Basin sediments. Geochim. Cosmochim. Acta, 46:59-68.

Pisciotto, K. A., and Mahoney, J. J., 1981. Isotopic survey of diagenetic carbonates, Deep Sea Drilling Project Leg 63. In Yeats, R. S., Haq, 
B. U., et al., Init. Repts. DSDP, 63: Washington (U.S. Govt. Printing Office), 595-609.

Srivastava, S. P., Arthur, M., et al., 1987. Proc. ODP, Init. Repts., 105: College Station, TX (Ocean Drilling Program), 917.

Stumm, W., and Leckie, J. O., 1970. Phosphate exchange with sediments; its role in the productivity of surface water. In Advances in Water Pollution Research, Vol. 2: New York (Pergamon Press).

Stumm, W., and Morgan, J. J., 1970. Aquatic Chemistry, An Introduction Emphasizing Chemical Equilibria in Natural Waters: New York (Wiley Interscience).

Strickland, J.D.H., and Parsons, T. R., 1968. A Handbook of Seawater Analysis: Ottawa (Fish Res. Board Can.), Bull. 167.

Tassé, N., and Hesse, R., 1984. Origin and significance of complex authigenic carbonates in Cretaceous black shales of the Western Alps. J. Sediment. Petrol., 54:1012-1027.

Thomson, J., Higgs, N. C., Jarvis, I., Hydes, D. J., Colley, S., and Wilson, T.R.S., 1986. The behaviour of manganese in Atlantic carbonate sediments. Geochim. Cosmochim. Acta, 50:1807-1818. von Rad, U., and Botz, R., 1987. Authigenic Fe-Mn carbonates in the Cretaceous and Tertiary continental rise sediments of DSDP Site 603 off the eastern U.S.A. In van Hinte, J. E., Wise, S. W., et al., Init. Repts. DSDP, 93: Washington (U.S. Govt. Printing Office), 10611077.

Wada, H., Niitsuma, N., Nagasawa, K., and Okada, H., 1982. Deep sea carbonate nodules from the Middle America Trench area off Mexico, Deep Sea Drilling Project Leg 66. In Watkins, J. S., Moore, J. C., et al., Init. Repts. DSDP, 66: Washington (U.S. Govt. Printing Office), 453-474.

Date of initial receipt: 31 July 1987 Date of acceptance: 3 February 1988 Ms B105-174 


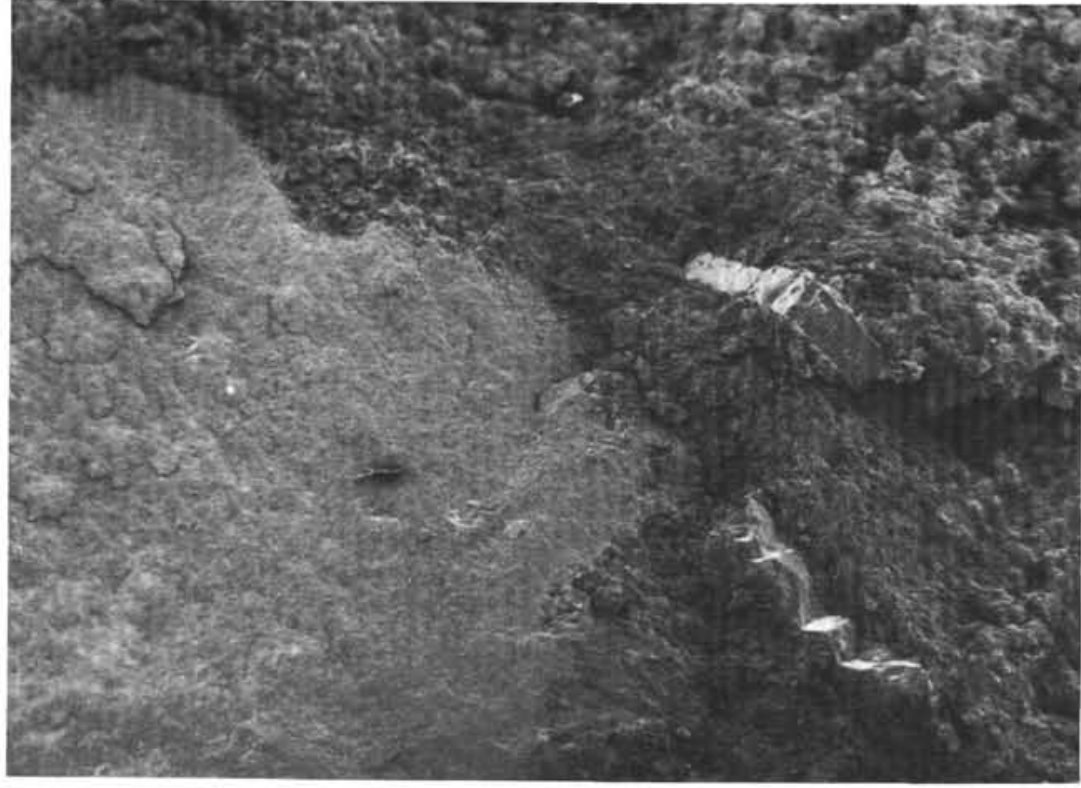

1

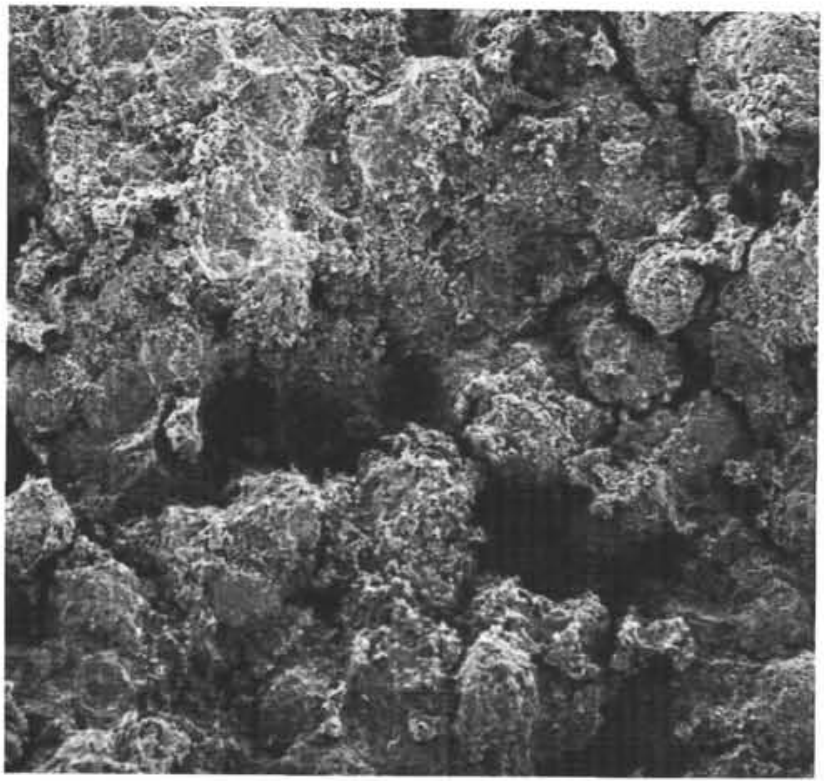

3

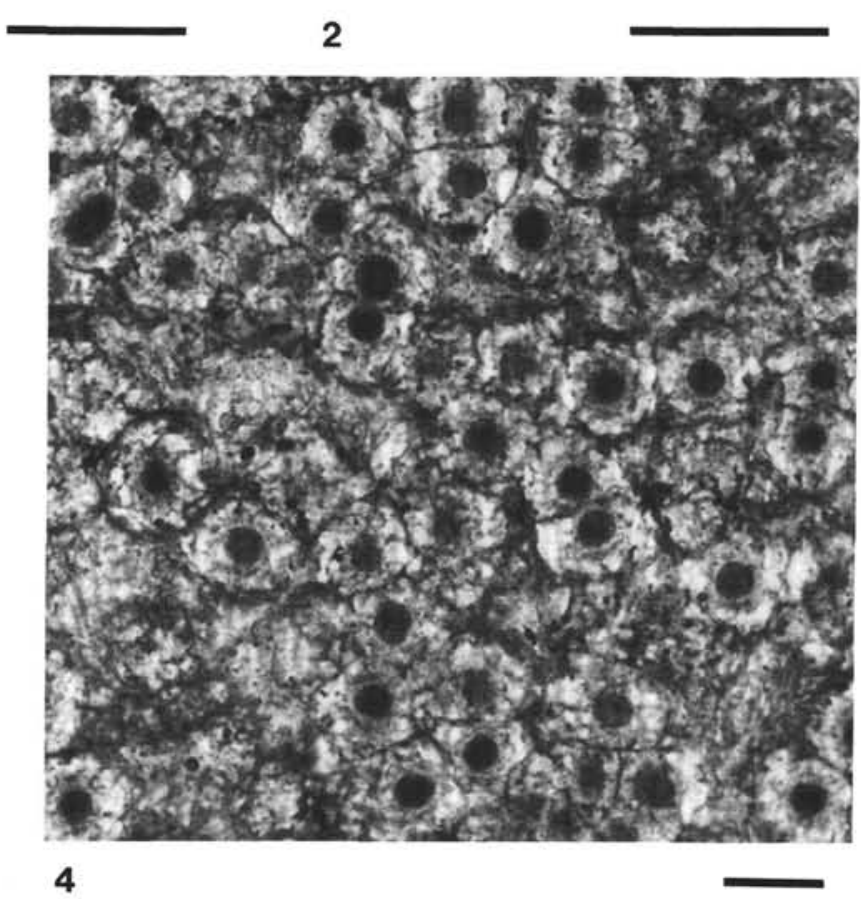

4

2

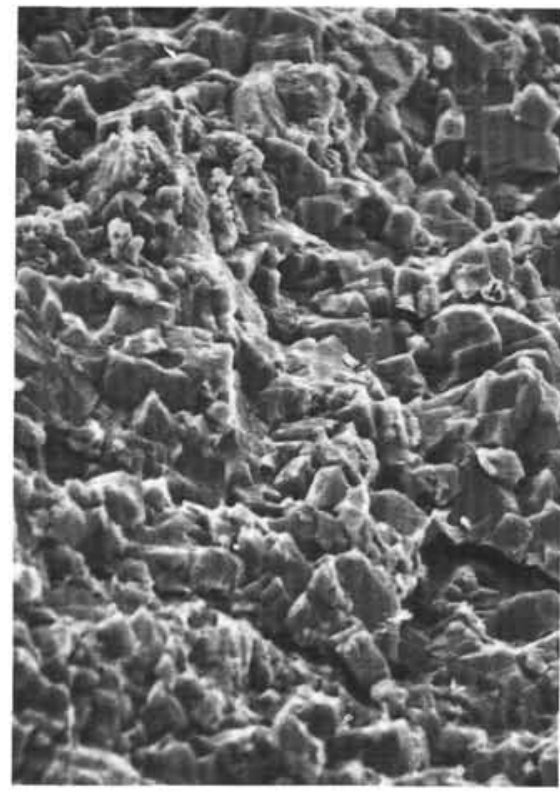



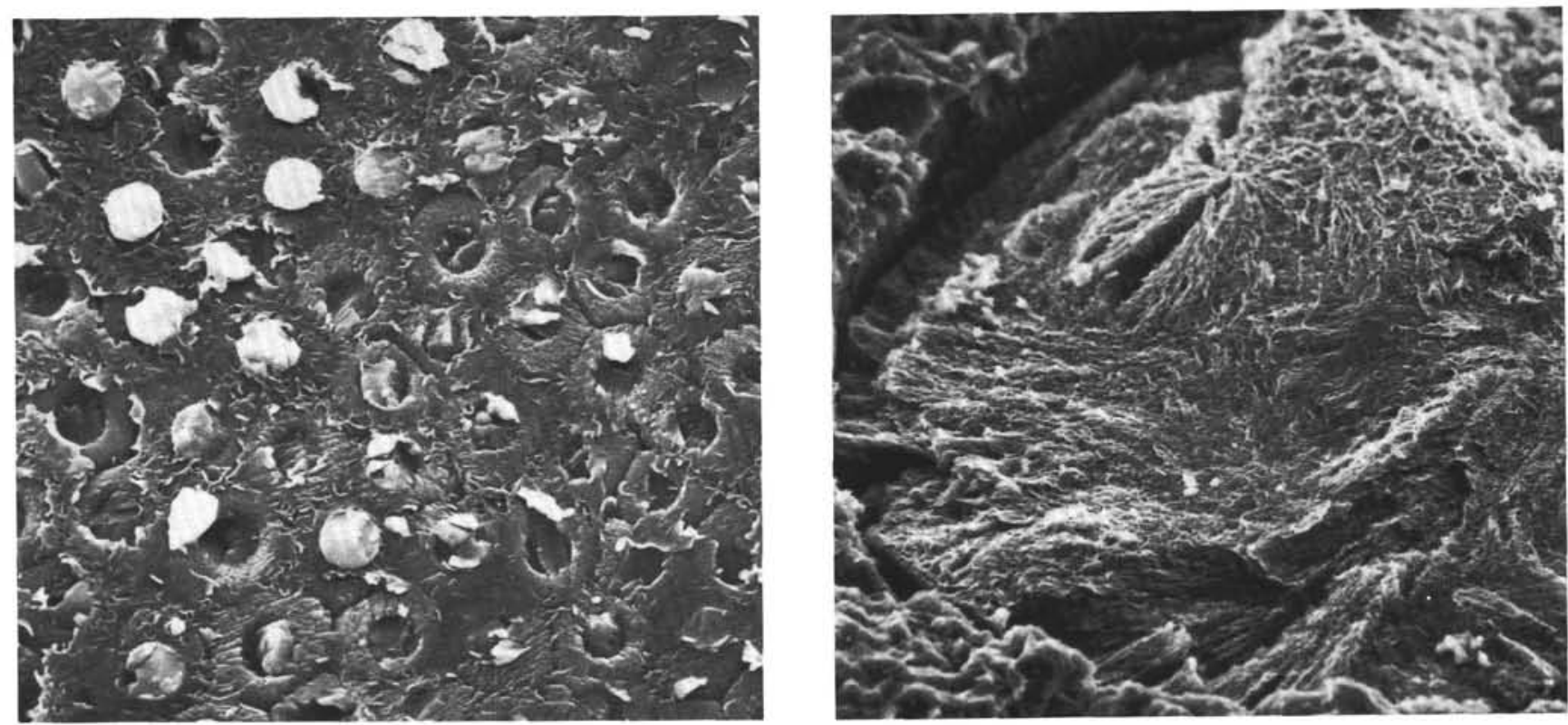

1

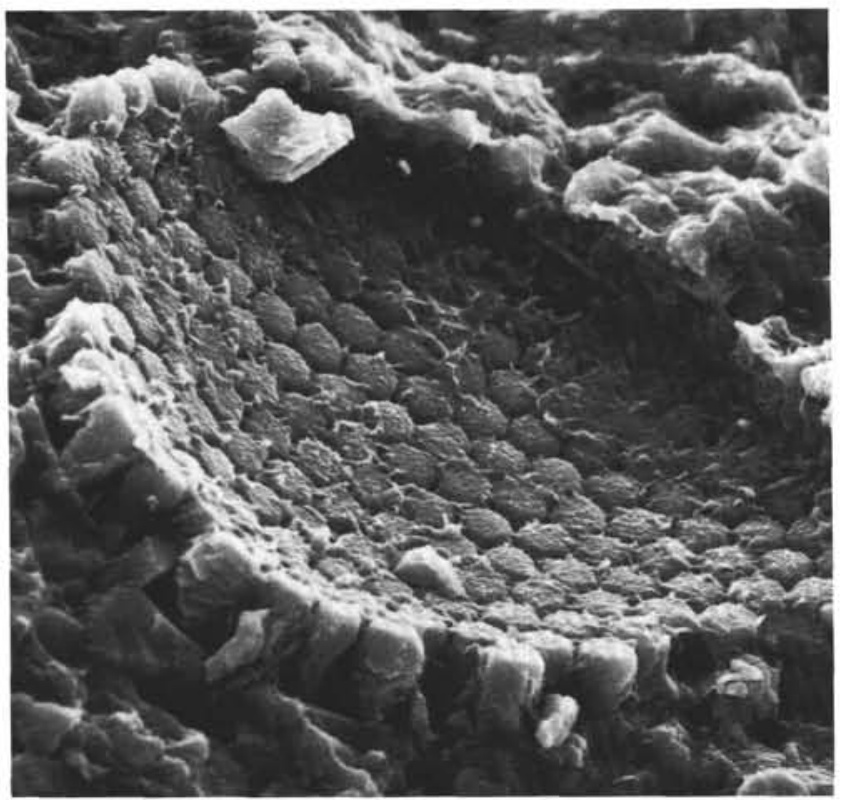

3

2

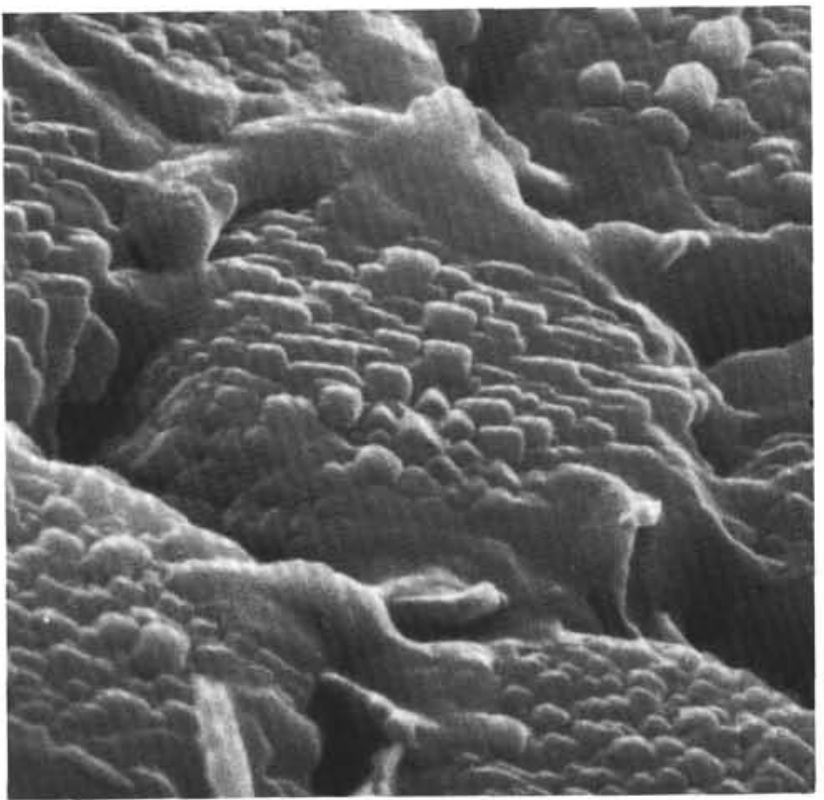

4

Plate 2. SEM photographs of diatom ghosts from Sample 105-647A-67R-1, 124-125 cm. 1. Diatom frustule completely replaced by authigenic iron-rich smectites (scale bar $=10 \mu \mathrm{m})$. 2. Massive, authigenic, iron-rich smectite replacing a diatom (scale bar $=40 \mu \mathrm{m})$. 3. The morphology of a centric diatom valve is preserved by a cast of all cavities with authigenic carbonate (scale bar $=10 \mu \mathrm{m}$ ). 4 . Closeup of picture 3 ; the fine carbonate rhombs preserve the original sieve structure (scale bar $=1 \mu \mathrm{m}$ ). 


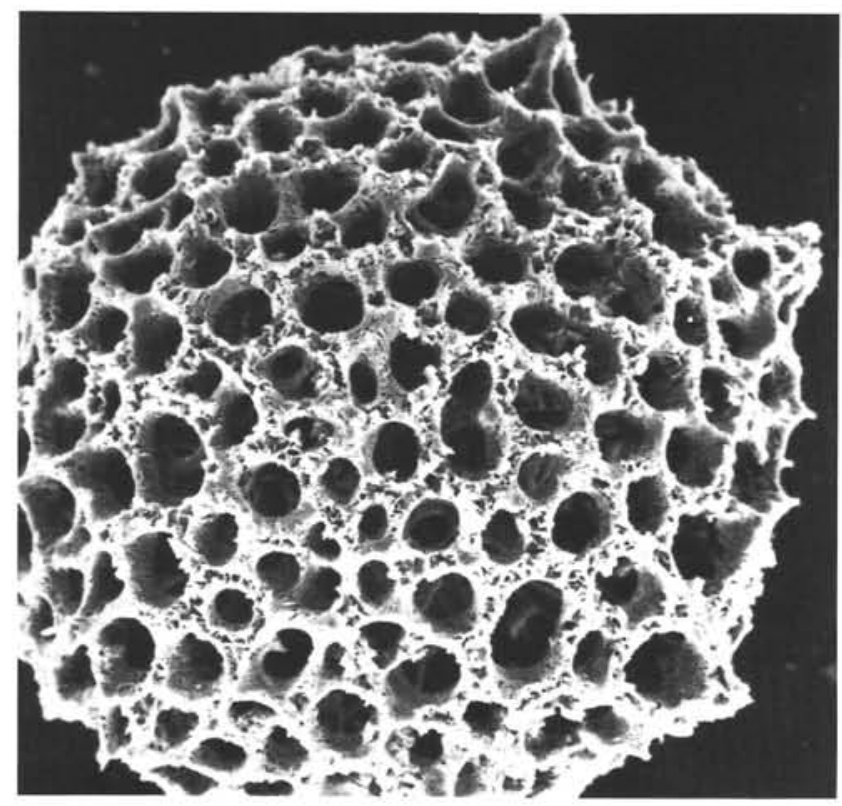

1

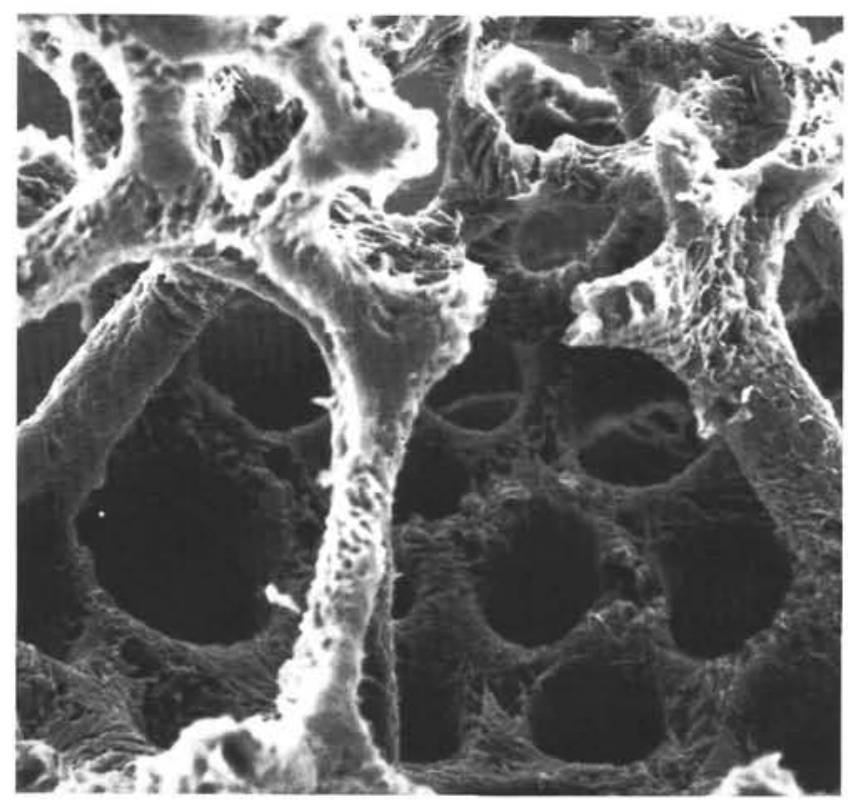

3

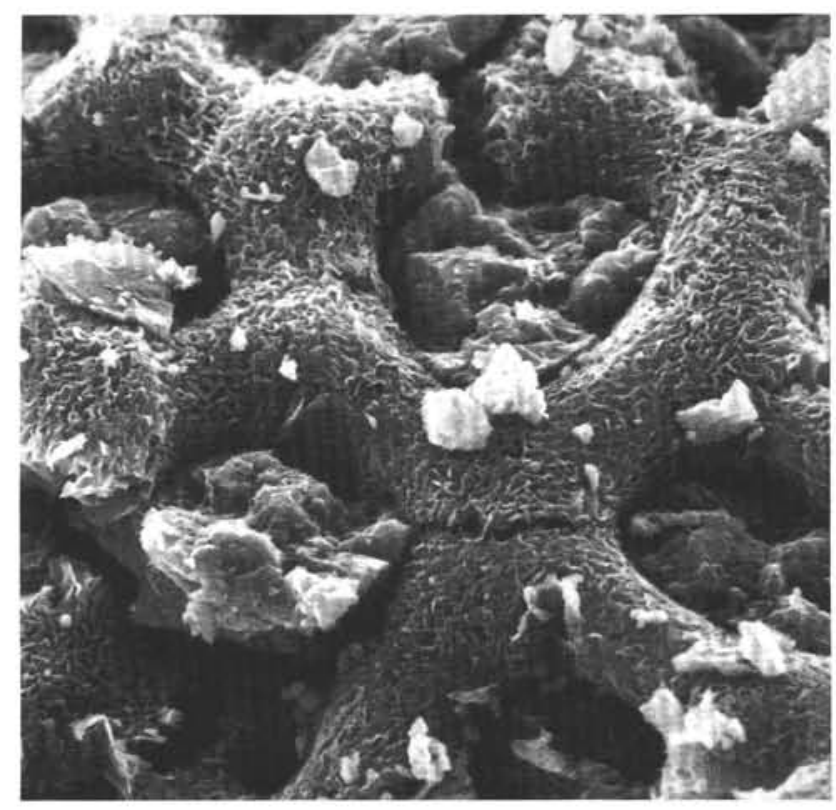

2

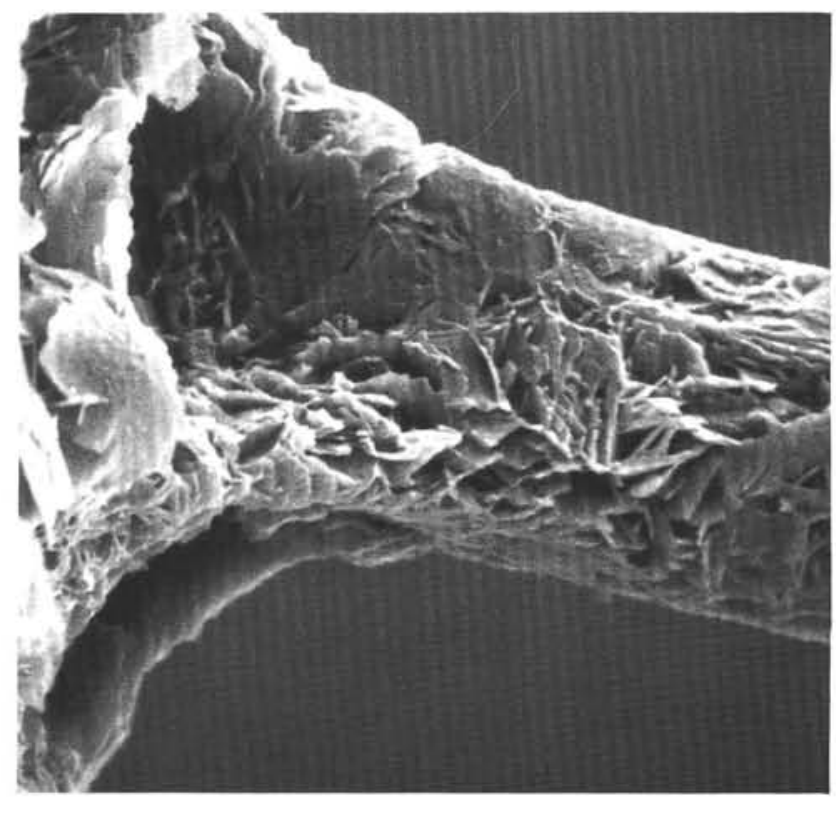

4

Plate 3. SEM photographs of radiolarians from the carbonate concretions. The original opal-A tests are completely replaced by mostly iron-rich smectites (Sample 105-647A-67R-1, 124-125 cm). 1. Test of an entire radiolarian (scale bar $=40 \mu \mathrm{m}$ ). 2. Skeletal detail of a radiolarian imbedded in authigenic carbonate (scale bar $=10 \mu \mathrm{m}$ ). 3. Detail of a radiolarian showing inner and outer capsula of a test well preserved by an authigenic clay-mineral fabric $($ scale bar $=10 \mu \mathrm{m})$. 4. Spine of a radiolarian showing in detail the intergrowth of smectites replacing the original opal-A skeleton $($ scale bar $=4 \mu \mathrm{m})$. 


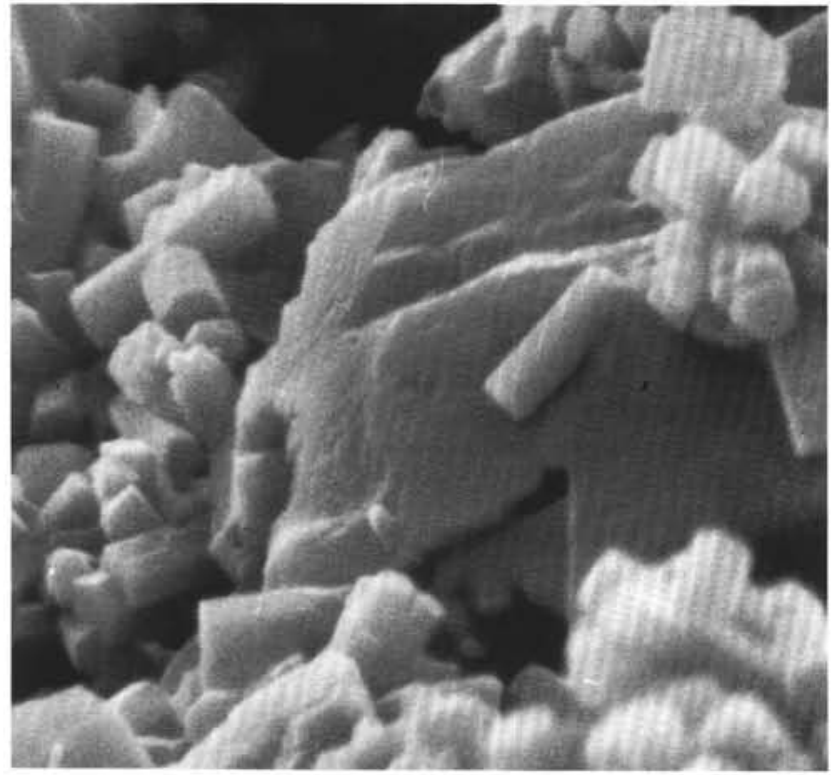

1

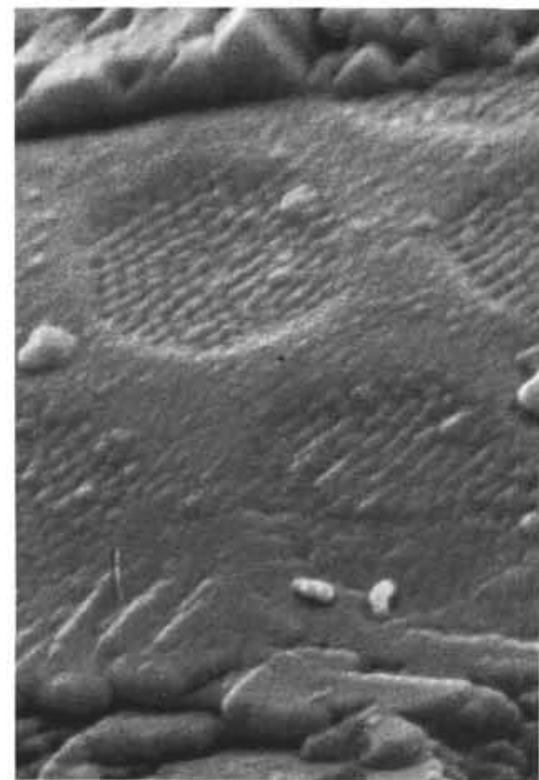

3

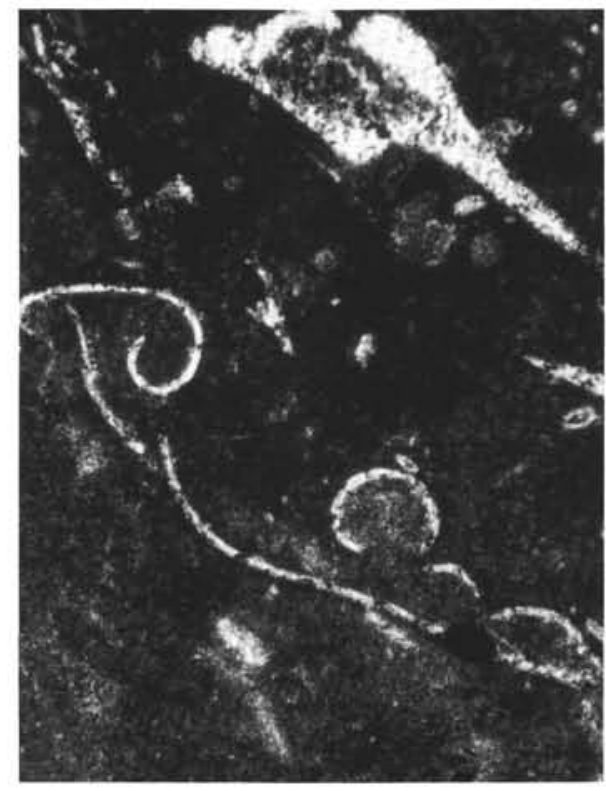

4

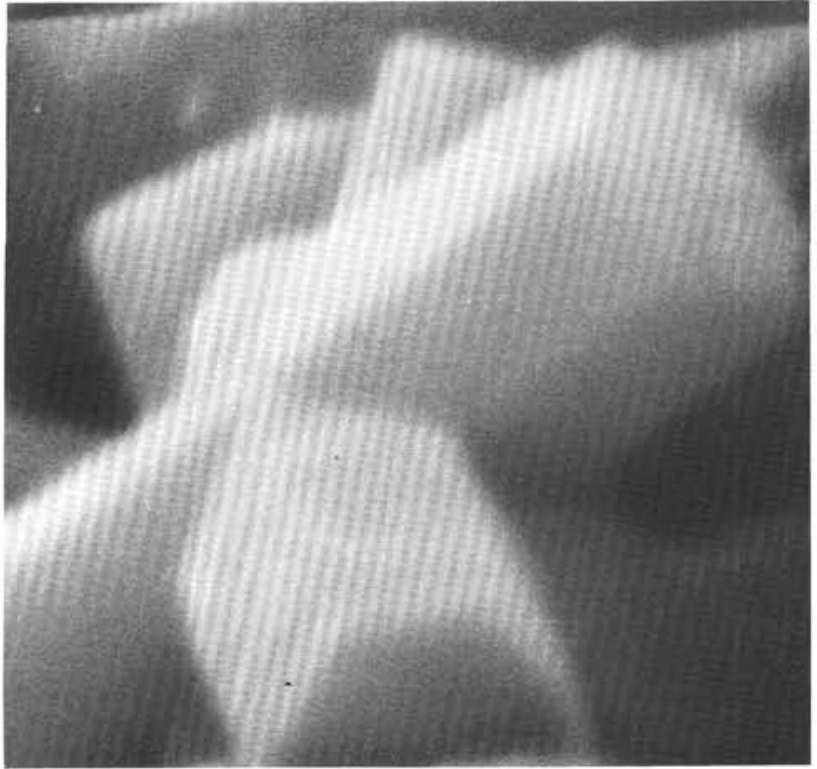

2

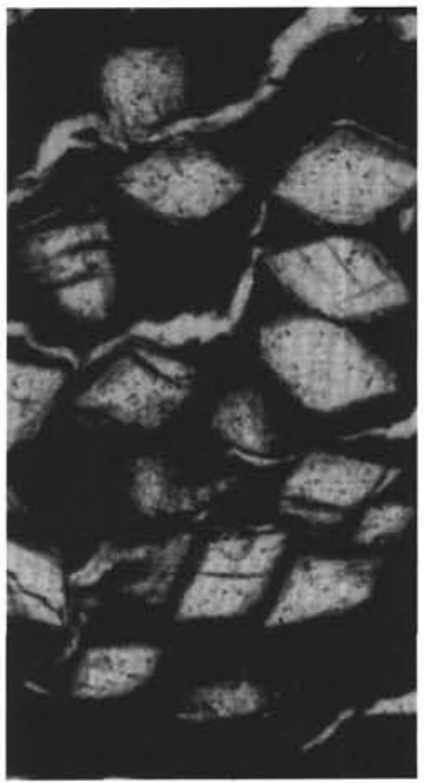

5

Plate 4. SEM (1-3) and thin section (4 and 5) photographs. 1. Tiny hexagonal apatite crystals growing on authigenic carbonates (Sample 105-647A64R-1, 85-90 cm; scale bar $=2 \mu \mathrm{m}$ ). 2. Closeup from picture 1 showing an apatite twinning (Sample 105-647A-64R-1, 85-90 cm; scale bar $=0.4$ $\mu \mathrm{m})$. 3. Cast of a diatom valve; the authigenic carbonate shows the structure of the sieve membrane, but has partly grown, further developing its own rhombohedral shape (Sample 105-647A-67R-2, 47-48 cm; scale bar $=2 \mu \mathrm{m}$ ). 4. Cross section of a phosphatic shell from a crustacean, which is well preserved in the carbonate concretion (Sample 105-647A- 67R-2, 47-48 cm; scale bar $=400 \mu \mathrm{m}$ ). 5. Carbonate rhombs of calcium-rich rhodochrosite grown in an iron-rich claystone matrix (Sample 105-647A-67R-2, 116-117 cm; scale bar $=30 \mu \mathrm{m}$ ). 


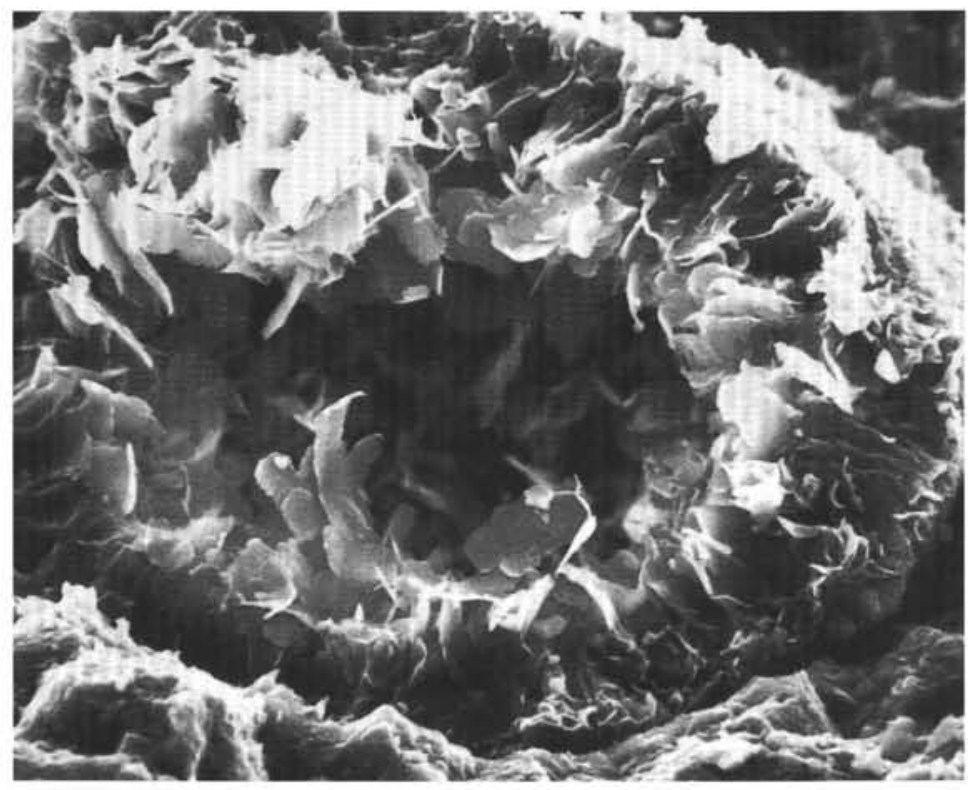

1

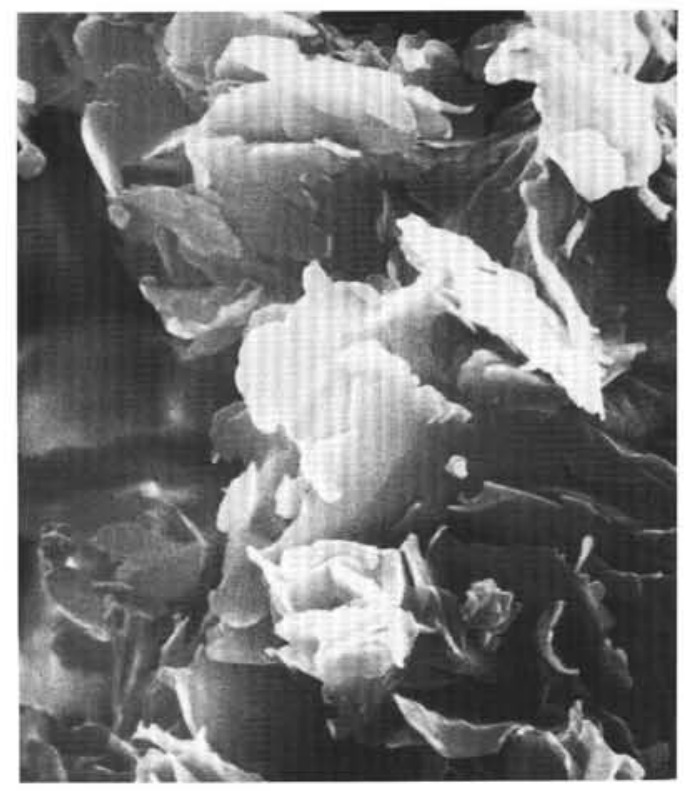

2

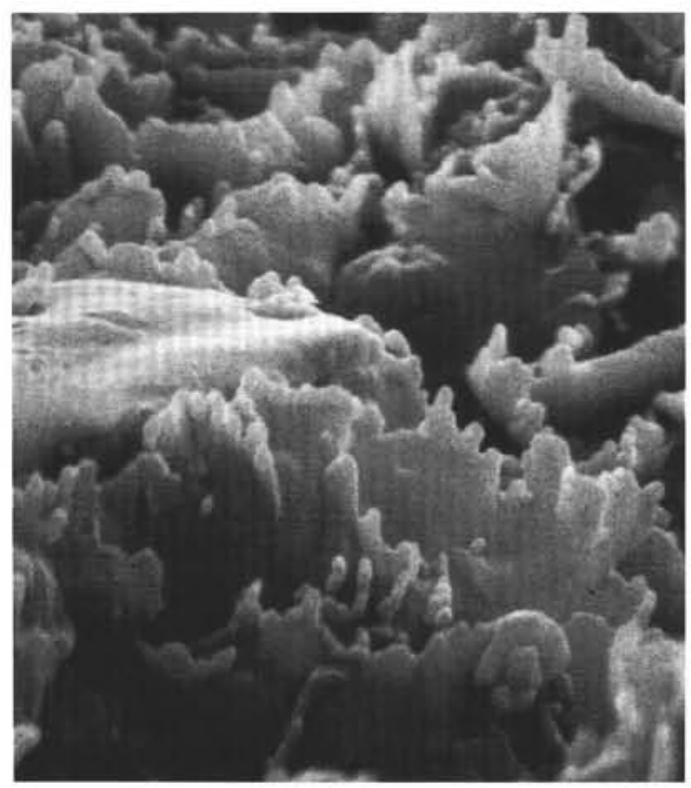

3

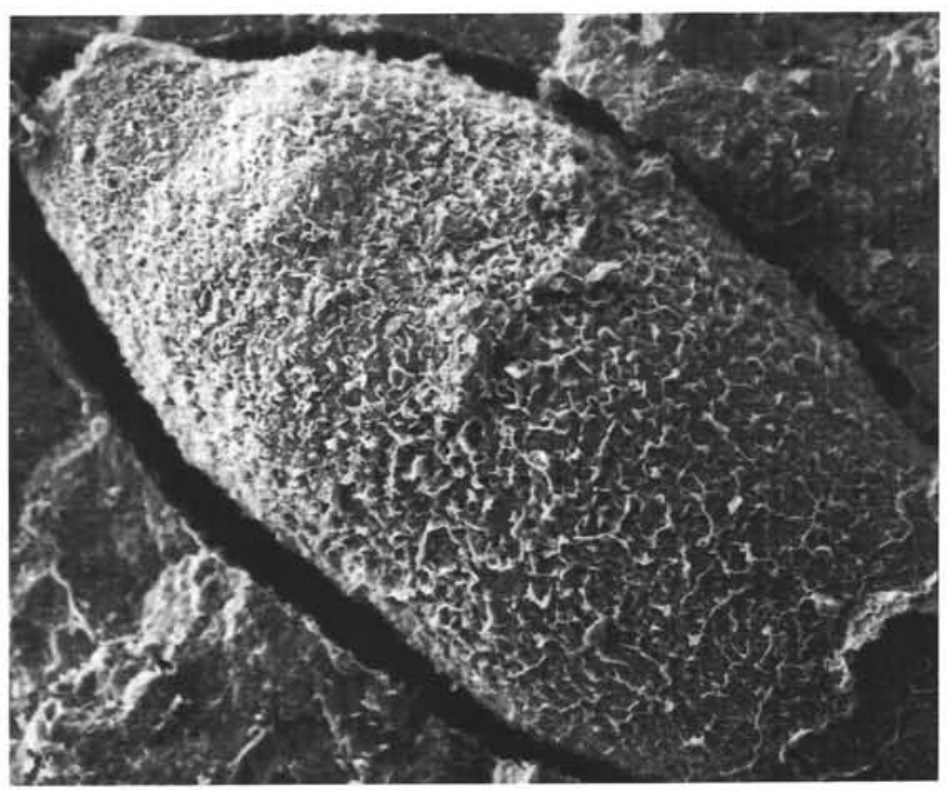

4

Plate 5. SEM pictures from authigenic clay mineral fabrics. 1. Ragged-edged flakes of smectite cement growing radially in a biogenic test (Sample 105-647A-67R-1, 124-125 cm; scale bar $=20 \mu \mathrm{m}$ ). 2. Detail of picture 1 (scale bar $=4 \mu \mathrm{m}$ ). 3. Authigenic fabric of flaky, ragged-edged smectites (Sample 105-647A-66R-3, 38-41 cm; scale bar $=2 \mu \mathrm{m}$ ). 4. Authigenic void-filling smectites in a biogenic test (Sample 105-647A-67R-2, 47-48 cm; scale bar $=40 \mu \mathrm{m})$. 